RUDIGER DORNBUSCH

Massachusetts Institute of Technology

FEDERICO STURZENEGGER

Massachusetts Institute of Technology

HOLGER WOLF

Massachusetts Institute of Technology

\title{
Extreme Inflation: Dynamics and Stabilization
}

WAR AND REVOLUTION were once the settings in which extreme inflation might occur: France in the period of the assignats; Europe in the 1920s; Greece, Hungary, and China in the aftermath of World War II. ${ }^{1}$ In the 1980s, the inflation net is cast wider. Israel had its high inflation experience in the early 1980s. Eastern Europe, in its transition to a market economy, is currently having its share: Poland and Yugoslavia have already had double-digit monthly inflation; Bulgaria and the Soviet Union may be next. In Latin America high inflation is the rule: Bolivia in 1984-85; Argentina, Brazil, and Peru are now experiencing wild price instability. In many of these cases, the fiscal consequences of a political transition, a terms of trade shock, or a debt crisis can be offered as the initiating disturbances.

Well over a thousand papers have been written about extreme inflation, including early analyses by Costantino Bresciani-Turroni,

We are indebted to our discussants, members of the panel, and to Eliana Cardoso, Phillip Cagan, Daniel Dantas, Hans Genberg, Danny Quah, and Steve Webb for helpful comments and suggestions. Miguel Cantillo contributed excellent research assistance. Financial support was provided by grants from the National Science Foundation and the Alfred P. Sloan Foundation.

1. See Seligman (1921) for the experience prior to the First World War; Cagan (1956), Yeager(1981), Young (1925), Sargent (1982), Dornbusch and Fischer(1986), and Harberger $(1978,1988)$ for later experiences. 
Frank Graham, and Phillip Cagan. ${ }^{2}$ Furthermore, interest grows as more is learned about the systematic patterns of high inflation, especially for countries where inflation is both chronic and extreme, though lower than the extravagant levels studied by Cagan. The formalization of concepts such as credibility and reputation has also increased interest in high inflation experiences by providing cleaner analytical models. ${ }^{3}$ The political economy literature, too, has contributed to the debate by explaining how hyperinflations start up, why their termination is so difficult, and what ultimately stops them.

This paper examines these issues and addresses two questions: What do we know about the process of high inflation-its sources, catalysts, and explosive behavior? What useful prescriptions are there for stabilization?

\section{Extreme Inflation}

High inflation means different things to different people. In Germany, it means 3 percent or more per year; in Mexico, 20 percent per year; in Brazil, 15 percent per month; and in Argentina, 6 percent per week. While Cagan defined hyperinflation as an inflation rate of 50 percent per month, or 12,875 percent per year, our threshold is a more modest 1,000 percent per year. ${ }^{4}$ In particular, we take extreme inflation to be rates above 15 to 20 percent per month, sustained for several months.

In either 1988 or 1989, 35 countries experienced annual inflation rates exceeding 20 percent. Of these countries, 9 experienced annual inflation above 100 percent, and only 5 had annual inflation rates above 1,000 percent. ${ }^{5}$ Clearly, extreme inflation is not a common occurrence. A first task, therefore, is to isolate those factors that explain why most countries do not cross the threshold to extreme inflation.

\section{Stabilizing Factors}

A major shock to the budget, the terms of trade, or the exchange rate is an essential ingredient for high inflation. An event such as a political

2. Bresciani-Turroni (1937); Graham (1930); Cagan (1956).

3. See, for example, Barro and Gordon (1983), Bruno (1990), and Kiguel and Liviatan (1990b).

4. Cagan (1956).

5. See IMF, International Financial Statistics. 
disturbance-in its most extreme form, war-or an abrupt international credit rationing may trigger the inflation. Countries that do not experience such a shock are unlikely candidates for an extreme inflation.

Even among those countries that experience a shock, the propagation of a price spiral may be dampened if proper action is taken. First, policymakers may offset the shock by corrective monetary and fiscal policies, rather than remain passive or accommodate the disturbance. Although such policies may slow growth, even to the point of recession, they surely stand in the way of accelerating inflation. Second, institutions may also enact stabilizing policies. Specifically, the disallowance of wage indexation can help avoid an inflationary spiral.

As for fiscal shocks, it is a long road from a budget deficit to a hyperinflation. A shock to a budget that is financed by domestic or external debt will not be inflationary, at least not in the short run. By contrast, if most of the deficit is financed by money creation rather than debt, inflation is more likely. In a country already demonetized by chronic inflation, extreme inflation becomes even more likely. In that case, a given deficit represents a large share of the existing money stock, and deficit finance thus becomes highly inflationary.

Highly unique conditions lead to extreme inflation. In addition to the shocks, a country must already be in a weakened state, and the process must be allowed to run its course unchecked for quite a while if it is to lead ultimately to extreme inflation. In several cases, the runaway process was decisively interrupted before control was lost. In France and Italy, in the period 1945-48, the price level tripled before stabilization put a stop to accelerating inflation. In Chile, in 1975-78, the price level increased eight-fold (nine-fold in Mexico between 1984-89) before stabilization occurred. In the experiences we study below, however, the deterioration was allowed to proceed much further, making hyperinflation a reality.

\section{The Starting Point}

Consider next how a high inflation process gets underway in three alternative environments. First, a country with chronically high inflation experiences a shock that leads to a sharp, possibly explosive, increase in prices. Brazil, Argentina, and Israel are examples given in table 1. The chronic presence of high inflation implies that these economies will have adapted to inflation-indexation may be common in labor and 
Table 1. Annual Rates of Inflation in Selected High Inflation Countries, 1975-90

Percent

\begin{tabular}{lcccr}
\hline Country & $1975-80$ & $1980-85$ & $1986-89$ & $\begin{array}{r}\text { Most recent } \\
12 \text { months }^{\mathrm{a}}\end{array}$ \\
\hline Argentina & 193 & 323 & 588 & 14,030 \\
Bolivia & 17 & 611 & 15 & 15 \\
Brazil & 51 & 149 & 610 & 6,407 \\
Israel & 61 & 195 & 19 & 20 \\
Mexico & 21 & 61 & 81 & 27 \\
Nicaragua & 19 & 54 & 3,130 & 10,531 \\
Peru & 50 & 102 & 693 & 2,864 \\
Poland & 7 & 32 & 90 & 994 \\
Yugoslavia & 18 & 47 & 343 & 1,876 \\
\hline
\end{tabular}

Source: IMF, International Financial Statistics, 1990 Yearbook and October 1990 editions, except 1989 data for Nicaragua, which was provided by the Nicaraguan authorities.

a. The average inflation rate over the most recent twelve months for which data are available for each country is shown.

financial markets. But this same indexation may prevent the economy from effectively absorbing shocks to relative prices and may leave the economy prone to hyperinflation. When indexing adjustments are infrequent, there is a long lag between shocks and their impact on wages. By contrast, when indexation occurs monthly or more frequently, the automatic feedback of disturbances to wages and prices, and back to the exchange rate, amounts to a rapid, vicious cycle of rising prices. The financial adaptation already in place-the easy availability of interestbearing assets-facilitates the flight from money.

The second possible scenario arises when a country with moderate inflation suffers a rapid, uncontrolled explosion in inflation due to a shock to the budget or the external balance. In table 1, Mexico could provide an example. In this situation, an outburst of inflation will surprise money-holders and may find the authorities unprepared for the rapid adjustments that the private sector makes.

Finally, an extreme inflation can occur in a country where inflation has been repressed and where deficit finance has built up a monetary "overhang." In this case, there is not only the ordinary flow problem of a budget deficit financed by money creation but also a stock problem in that the money supply is already too high relative to nominal income at controlled prices. Once prices are freed up, inflation gets rapidly underway. In the absence of strong stabilizing factors, it can become extreme 
very quickly. The fear of this type of explosive inflation led to pervasive monetary reform in Germany and elsewhere in the 1940s. ${ }^{6}$ Poland, in 1989 , is a more recent example. The Soviet Union and Bulgaria may provide the next examples.

A country's starting point is important because it bears on the dynamics of high inflation. Countries with chronic inflation tend to have a financial structure that is adapted to inflation; capital flight, the resulting exchange rate collapse, and the consequent explosive inflation may be stretched out over time. By contrast, in countries that have little experience with high inflation, primitive financial structures, and entirely unindexed fiscal institutions, an inflationary shock can set the house on fire in no time. Because the financial structure is so unadapted to inflation, there will typically be an initial phase in which real balances rise rapidly as a result of deficit finance. If no interest-bearing assets are available and dollar-holding is uncommon, little adjustment to real balances takes place initially. Later, as escalating inflation becomes apparent, the flight from money into foreign assets accelerates dramatically.

\section{Are All Hyperinflations Alike?}

High inflation experiences have many common, systematic features including demonetization, growing deficits, and accelerating frequencies of wage and price adjustment. High inflations also differ from one another. For example, the great inflations of the 1920s were considered extreme aberrations, which could be remedied by a return to the gold standard. By contrast, the current inflation in some Latin American countries remains endemic, and has no certain cure.

The recent Latin American experience differs from those of the 1920s in three ways. First, the inflations in Latin America, and also in Israel prior to the 1985 stabilization, have lasted longer. They have extended over a decade or more through the intermittent but persistent acceleration of inflation. Second, current inflation rates remain far below those of, for example, Germany in the second half of 1923, where inflation averaged 4,551 percent per month. Third, in recent times there has been a stop-go pattern of inflation-temporary stabilizations are followed by major blowups. The temporary stabilizations initially seem to prevent

6. Dornbusch and Wolf (1990). 
the dramatic escalation into hyperinflation, but the successive rounds of stop-go policies raise the average monthly inflation rates and may only delay the escalation. ${ }^{7}$ The stop-go pattern of Latin American inflation, as we shall see below, has important implications for stabilization.

\section{Traditional Approaches}

A stark monetary view of extreme inflation is offered in Cagan's classic model. ${ }^{8}$ In his theory, inflation is determined in the money market, and its pace is set by the growth rate of money and the evolution of inflationary expectations, which are the sole determinants of velocity. In the absence of other financial assets, expected inflation measures the alternative cost of holding money. Inflationary expectations are formed adaptively, and the nominal money supply grows at an exogenous rate. Other real variables, particularly output, that may affect real money demand are considered invariant. Inflation is determined by monetary equilibrium alone; the goods and labor markets play no role. Finally, the economy is closed. With these assumptions, the model takes the form,

$$
\begin{gathered}
M / P=L\left(\pi^{*}\right), \\
\dot{\pi}^{*}=\alpha\left(\pi-\pi^{*}\right),
\end{gathered}
$$

where $\pi$ and $\pi^{*}$ denote actual and expected inflation. Differentiating equation 1 with respect to time, and letting $\mu$ denote the percentage growth rate of the nominal money supply and $\beta$ denote the semielasticity of real money demand, we obtain

$$
\pi=\left(\mu-\alpha \beta \pi^{*}\right) /(1-\alpha \beta), \text { where } 1>\alpha \beta .
$$

The model predicts that if the rate of money growth is increased and sustained at its new level, the rate of inflation jumps above the rate of money growth and then gradually falls until it equals the rate of money growth. We illustrate this point in figure 1. In the adjustment process, real balances decline accordingly. Expected inflation gradually rises as expectations are revised upward until the gap between actual inflation and prevailing expectations is closed.

Arguments surrounding Cagan's basic model have broadly addressed

7. Canavese and Di Tella (1988) and Heyman (1990).

8. Cagan (1956, 1987) and Friedman (1956). 
Figure 1. Adjustment to a Sustained Increase in Money Growth

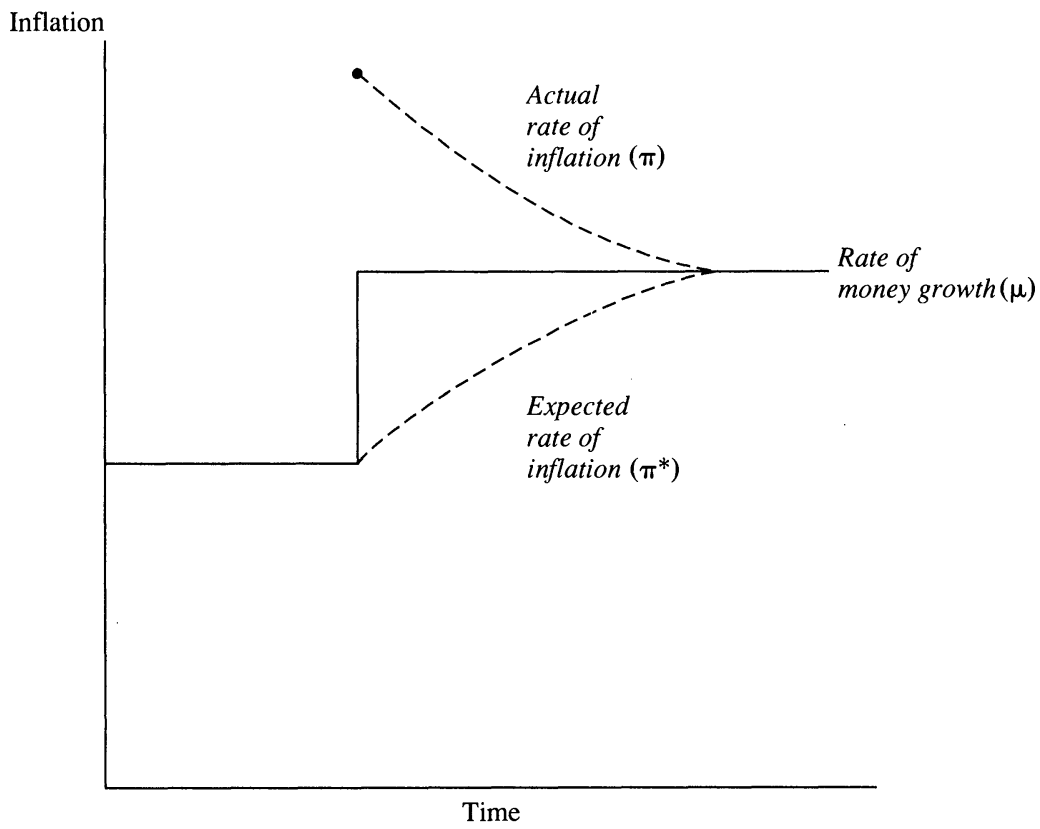

three issues: the expectations mechanism, the assumptions about money growth, and the assumptions about the determinants of inflation. Criticism of the expectations mechanism, notably the rational expectations attack, has focused on the serial correlation of forecast errors in the adjustment process. An alternative model would emphasize fully rational expectations. ${ }^{9}$ When perfect foresight is assumed, two differences with the previous analysis emerge. First, the price level is allowed to jump. Second, actual and anticipated inflation are equal, $\pi=\pi^{*}$.

In this forward-looking model of inflation, an increase in the growth rate of nominal money immediately raises both the price level and the rate of inflation. Thus, real balances instantly decline to the level appropriate to the higher growth rate of nominal money and prices. Full adjustment to an increase in money growth occurs immediately; there are no protracted dynamics. Anticipated, future money growth still leads

9. Sidrauski (1967), Sargent and Wallace (1973a), Black (1974), Sargent (1977), Salemi and Sargent (1979), and Flood and Garber (1980). 
to a jump in the current price level, but now inflation rises gradually until money growth increases.

\section{A New Approach}

We depart from the Cagan model and the related literature in several ways. Although the rational expectations formulation is theoretically attractive, it does not reflect the facts. Increased money growth initially tends to raise real balances; only later does inflation build up and overshoot for a while. ${ }^{10}$ Figure 2 shows the example of Peru after 1985. In our model, we emphasize that prices are set rather than determined by an invisible, money market-clearing hand. The price setting, in turn, is dependent on the prevailing inflationary regime.

A second difference in our model concerns financial markets. The assumption that money is the only asset is patently misleading. Some countries do have domestic financial markets. When they do not, the dollar usually plays a conspicuous role as an alternative asset. The availability of alternative assets influences the dynamics of inflation.

The third difference in our model concerns the process of money growth, and the motivation a government may have to create or accommodate inflation. As a theory of inflationary finance, the Cagan-Chicago tradition has emphasized that governments use inflation as a rational means of raising revenue for deficit inance. This approach has led to models of optimal inflation, which balance revenue considerations and various constraints or costs associated with inflationary finance. ${ }^{11}$ In their simplest form, such models predict that a government maximizes seigniorage by choosing the rate of inflation at which the elasticity of real money demand with respect to anticipated inflation equals unity, or the peak of the Laffer curve.

Martin Bailey has questioned the use of the seigniorage approach as a positive theory of extreme inflation. ${ }^{12}$ Because taxation is an alternative to money creation and because the marginal cost of taxation is moderate relative to the welfare costs of extreme inflation, high money growth (and therefore high inflation) strategies are not optimal. In our view,

10. Friedman and Schwartz (1982) set out this pattern.

11. See Cagan (1956), Bailey (1956), Friedman (1971), Barro (1972a, 1983), and Bruno (1990).

12. Bailey (1956). 
Figure 2. Peru: Real Money, 1985-90

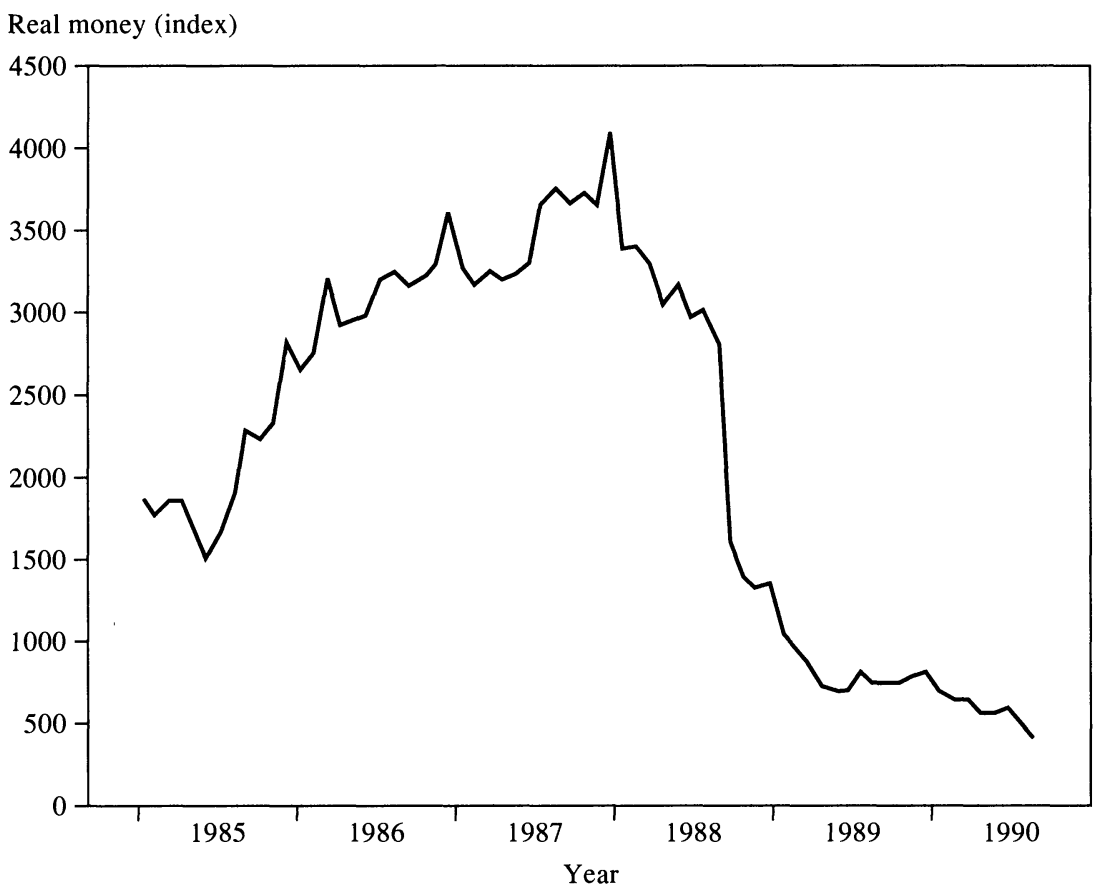

Source: Authors' own calculations using Central Bank of Peru, Weekly Bulletin, various issues.

a. Real money is the nominal money supply in the local currency divided by the CPI $(1989=100)$.

extreme inflation reflects a state of fiscal chaos, not optimal public finance.

Neither money nor the budget is exogenous in a high inflation process. We show that higher inflation leads to larger deficits and greater money creation unless governments actively intervene to change the fiscal structure. Moreover, even if they do act, the pace at which inflation can destroy the fiscal system may well outrun the government's attempt to reform the system.

This observation leads to a fourth difference in our model. We view high inflation as intrinsically unstable. Shocks to high inflation economies easily translate into explosive inflation until a fundamental stabilization program can reset the dials. If correct, this view raises the question of why a government would allow explosive inflation to occur rather than stabilize early. Answers to this question must come from a political 
economy approach that analyzes the difficulty in bringing about a balanced budget and illustrates how extreme inflation is a negative sum game. With the seigniorage approach one would expect stable, steadystate inflation. The political economy approach, however, may explain why inflation explodes, only to be stabilized later, and why rational governments make U-turns in economic policy. ${ }^{13}$

In conclusion, the view that inflation is about too much money chasing too few goods is not totally wrong, but it fails to give a useful idea of what in fact happens. First, the influence of inflation on the budget deficit is a critical element in the inflation. Second, the inflation process is significantly affected by the adaptation of financial institutions. The emergence of new financial products such as overnight, interest-bearing deposits affects the government's ability to collect seigniorage and hence shapes the inflation process. Third, the inflation process is driven in part by the pricing rules of economic agents in the goods and factor markets. A shortening of adjustment intervals becomes a factor in inflation that is independent of aggregate demand. Finally, as we discuss below, the external sector can play a critical role in the inflation process because real exchange rates are not constant. Indeed, the assumption of purchasing power parity is empirically unwarranted. As a result, shocks to the real exchange rate can precipitate high inflation.

\section{Inflation, Money Growth, and the Budget}

In this section we discuss the links between the growth rate of nominal money, the budget deficit, and the rate of inflation. We emphasize two factors. First, money growth is endogenous; money passively finances budget deficits. Second, the real budget deficit is not exogenous because inflation affects the real level of revenues.

The inflationary equilibrium is described by monetary equilibrium and the link between money creation and the budget deficit: ${ }^{14}$

$$
\dot{M} \mid P=\theta Y,
$$

13. For explorations in this direction, see Alesina and Drazen (1990), Cukierman, Edwards, and Tabellini (1989), Orphanides (1990); and, in another context, Fernandez and Rodrik (1990).

14. We note that the budget deficit includes the "quasi-fiscal" deficit that arises from the credit and foreign exchange operations of the central bank. Also, money issued by state and local governments, by corporations, and even by private entrepreneurs is often significant. The seigniorage shared by the banking system and other money issues necessarily increases the inflation rate associated with any given budget deficit. 
where $\theta$ is the budget deficit as a share of real GDP, $Y$. Suppose now that velocity is a linear function of inflation, $V=\alpha+\beta \pi$. Imposing monetary equilibrium and the steady-state condition that velocity be constant (so that inflation equals nominal money growth), we obtain an expression for steady-state inflation:

$$
\pi=\alpha \theta /(1-\beta \theta) .
$$

It is apparent from the functional form that inflation is an increasing, nonlinear function of the budget deficit. ${ }^{15}$

The interaction between the budget and prices-both their level and their rate of change-may go in one of two directions. Either fiscal drag and the reduction of the real value of debts dominate, in which case inflation reduces deficits. Or, inflation worsens deficits because of collection lags that reduce real revenues. During the hyperinflation of the 1920s, it was generally acknowledged that inflation reduced the real revenue of governments and that, by implication, deficits would be smaller if inflation could be reduced. ${ }^{16}$ The adverse response of deficits to inflation is now known as the Tanzi effect. ${ }^{17}$

We identify five channels through which inflation affects the deficit.

- Lags in collection in a less than fully indexed tax system lead to the erosion of real revenues, not only automatically, but also from the additional erosion that results from manipulated delays in payment.

- Tax compliance deteriorates, and so the tax yield of a given tax structure declines. This effect is a by-product of inflation and public demoralization; it is not a mechanical effect.

-The real value of payments on long-term debt, fixed in nominal terms, declines. This mechanism was important in the 1920s but is marginal in the experiences of the 1980s.

-With increased inflation and unchanged indexation intervals for wages, the average real public sector wage between adjustment dates declines.

-Nominal interest payments on short-term domestic debt come to

15. An alternative specification is the Cagan form which yields $\theta=\pi e^{-\lambda \pi}$. Because the right-hand side has the Laffer curve property, there are two equilibria unless the deficit is too large to be financed by money creation at constant inflation. See Evans and Yarrow (1981), Cardoso (forthcoming), Kiguel (1989), and especially Bruno and Fischer (1990) on the implications of the Laffer curve.

16. See Bresciani-Turroni (1937), Graham (1930), and League of Nations (1946).

17. See Olivera (1967), Dutton (1971), and Tanzi (1977, 1978). 
include an inflation premium, giving rise to the distinction between actual and inflation-adjusted debt service.

The effects of inflation on the budget are difficult to establish empirically because they are obscured by other effects: the interaction of automatic effects like inflationary erosion; the shortening of adjustment lags; and the introduction of changes in the tax rate, the tax base, and tax administration. Therefore, we must look at individual cases in order to show that a decline in revenue is a striking fact of high inflation and that while real spending also falls, the decline is not commensurate.

For example, consider the German hyperinflation. If the real value of tax revenue is taken as 100 in 1921 , it declines to 45 by 1922 . Over the same period, the real value of the public debt was basically wiped out, though the net effect was still a dramatic widening of the deficit. ${ }^{18}$ Table 2 shows the example of Peru in the 1980s.

In the hyperinflations of the $1980 \mathrm{~s}$, the public enterprise sector systematically contributed to the enlargement of deficits. The lack of full indexation of public sector prices, such as for energy, transport, and telephones, had been welcomed and used pervasively by policymakers because it slowed inflation; yet, the public sector deficit widened as a result. While it is intended to maintain the living standards of the poor, the policy's true effects have often been random and sometimes outright regressive.

The link running from inflation to the budget, and hence to money creation, affects inflation dynamics. The deficit, measured as a share of GDP, becomes a function of the inflation history and of any responses to inflation such as indexation, the shortening of tax collection lags, or changes in the tax structure.

In this scenario, the vulnerability of the real deficit depends on the relative strength of tax indexation and collection lags, for some given distribution of outlays and revenue. We would expect that, in the face of rising real deficits, efforts will be made to increase the real tax yield by shortening lags and increasing the degree of tax indexation. A simple model conveys the effects. Inflation proceeds at the constant rate, $\pi$, and nominal income is taxed at a constant rate, $v$. The fraction of past 
Table 2. Peru: Public Finance Data, Expressed as Percent of GDP, 1985-89

Percent

\begin{tabular}{lccccr}
\hline & 1985 & 1986 & 1987 & 1988 & 1989 \\
\hline Tax collection & 13 & 11 & 9 & 7 & 4 \\
Public enterprise revenue & 26 & 18 & 14 & 12 & 10 \\
Budget deficit & 6 & 10 & 12 & 14 & 11 \\
\hline
\end{tabular}

Source: Unpublished World Bank data.

tax revenue collected today decays exponentially with a mean lag of $\sigma$. In that case, the deficit ratio is

$$
\theta=g-v /(1+\sigma \pi),
$$

where $g$ denotes real government spending as a fraction of GDP, and $\sigma$ can assume a value between zero and infinity (the closer to zero, the more current the collection). Equation 6 shows that the more current the tax collection, the higher is the real revenue. It also shows that the higher the rate of inflation, the lower the real yield of a given tax structure. For a given collection lag, an extreme increase in the rate of inflation will basically wipe out revenue.

Given the velocity equation and the noninflationary deficit $(g-v)$, the longer the average lag in tax collection, the higher is the steady-state rate of inflation. Moreover, given the nonlinearities, even small increases in the deficit can produce large changes in inflation. ${ }^{19}$

Equation 6 focuses on the case of a constant-inflation history. Yet, when inflation has been rising, the current real value of tax collection will depend on the history of inflation acceleration. The sharper the acceleration becomes, relative to the lag in tax collection, the further real revenue falls compared to the constant-inflation-rate formula. In the simulations below, this complication emerges as a critical destabilizing element.

To summarize, the endogeneity of the money stock is an important feature of hyperinflation. In economies where money creation is the only means of deficit finance, the budget deficit becomes a principal determinant of money growth. In addition, faster money growth leads to

19. It is apparent from the nonlinearities in equations 2 and 3 that equilibrium need not be unique. 
higher inflation which, in turn, determines the deficit. The interaction is highly nonlinear, which helps explain the sharp escalation of inflation that can occur once a certain threshold is crossed. A simulation model presented below displays that characteristic in a setting where pricing decisions and the velocity response to inflation are optimized. It becomes evident that extreme inflation emerges in those cases where the government has lost control over money growth because the deficit is financed automatically. To make things worse, the deficit itself responds positively to the rate of inflation.

\section{Pricing}

The interaction between inflation and the frequency of price adjustment represents the second building block of inflationary dynamics. Economic agents incur costs in adjusting prices. Thus, the optimal frequency for adjusting prices depends on these "menu costs" and the trend rate of inflation. The frequency of adjustment becomes endogenous in a high inflation economy, with the shortening of the adjustment interval accelerating inflation which, in turn, leads to a further shortening of adjustment intervals. Without monetary accommodation this process could not go far. But, as already noted, money growth is endogenous through budget deficit finance. Thus, the shortening of adjustment intervals becomes another endogenous driving force in the inflation process.

Strategic interaction among price setters is an important feature of the growing literature on optimal price adjustment in stochastic inflationary economies. ${ }^{20} \mathrm{We}$ are interested in the fact that the frequency of adjustment accelerates with inflation. We also want to learn more about the thresholds of inflation at which the shortening of pricing intervals occurs.

\section{The Firm and the Industry}

Individual firms face the microeconomic decision of how often to change prices. Consider a loss function for an individual firm in which

20. See Barro (1972b), Mussa (1981a), Sheshinski and Weiss (1983), Rotemberg (1983), Cecchetti (1986), Benabou (1988), and Diamond (1990) for models of optimal pricing rules. 
the fixed cost of price adjustment is denoted by $c$. In addition, the firm's profit depends on the relative price of its product with respect to the entire economy, which we proxy by taking the square of the rate of inflation divided by the frequency of adjustment, $n$;

$$
Z=c n+\phi(\pi / n)^{2} .
$$

The firm selects the optimal adjustment frequency, $n^{*}$ :

$$
n^{*}=\left(2 \phi \pi^{2} / c\right)^{1 / 3} \text {. }
$$

Thus, the firm adjusts prices more frequently the higher the rate of inflation. ${ }^{21}$

Across industries, the frequency increases as the fixed cost of adjustment decreases and misaligned relative prices become more costly. Equation 8 indicates a continuous relation between inflation and the frequency of price adjustments. In fact, the importance of inflation is probably noticeable only when inflation becomes considerable. Then, shifts from say annual to quarterly, monthly or even weekly adjustment can be expected.

Note that we might also interpret the shortening of adjustment intervals as a response to increased uncertainty. If high inflation also means more variable inflation over a specified horizon, firms may adjust to the increased uncertainty by shortening their pricing horizon. ${ }^{22}$ If inflation uncertainty is proportional to the level of inflation, a longer pricing interval implies increased uncertainty of relative prices. Accordingly, the term $\pi / n$ may reflect uncertainty about the firm's relative price.

When inflation becomes extreme, price setting occurs in dollars so that prices in the local currency are fully flexible. The shift to dollar pricing occurs when the value of the dollar becomes a better indicator of the current domestic price level than information contained in past rates of inflation.

21. The analysis is easily adapted to an industry setting by modifying the objective function to be $Z=c n+\left[\phi(\pi / n)^{2}+\nu \pi\left(n^{\prime} / n\right)^{2}\right]$, where $n^{\prime}$ is the industry adjustment frequency observed by the individual firm. Solving for the firm's optimum and imposing $n^{*}=n^{\prime}$ yields the symmetric industry equilibrium where now the cost parameter, $\nu$, influences the equilibrium frequency.

22. The existence of a positive relationship between the level and the variability of inflation has been extensively documented. See, for example, Mitchell (1927), Mills (1927), and Fischer (1981). Of course, variability does not imply uncertainty. For present purposes, however, we are happy to make this further leap of faith. 


\section{Relative Prices}

When aggregate inflation is moderate, firm and industry prices change infrequently, perhaps once a year. With higher inflation, price adjustment may be semiannual, quarterly, or ultimately monthly, weekly, even daily. In the limit, indexation to the dollar becomes the only way a firm can judge its relative price position given the prohibitive costs of ascertaining the current price level. Because the pricing by firms and industries translates into an aggregate rate of inflation, their prices have spillover effects: on the pricing of labor, including official minimum wage and public sector wage setting; on the adjustment of prices for public services; and, importantly, on the exchange rate.

Public sector price adjustment should follow the same logic as firms' pricing decisions, though it rarely does. The data in table 2 give a fair idea of the fiscal effects of misaligned relative prices in an extreme inflation country, Peru. As inflation accelerates, both tax revenue and public enterprise revenue decline as a share of GNP.

It is less evident that menu costs are important for exchange rate adjustments. Therefore, governments might choose to move exchange rates almost continuously in order to maintain their real value. Indeed, several countries, for example Brazil in the 1970s, have done just that. But, as with public sector prices, exchange rates are a seemingly attractive means of dampening inflation in the short run, and so they are abused for that end.

\section{Evidence on Pricing}

The general pattern of price adjustment is shown below. We note that with increasing inflation all price setting speeds up and slower-moving prices would catch up.

\begin{tabular}{lll}
\multicolumn{3}{c}{ Speed of adjustment } \\
\hline Frequent & Intermediate & Slow \\
Exchange rate & Public prices & Wages \\
WPI & CPI &
\end{tabular}

The increasing synchronization that emerges during a shift to high inflation can be seen from the cross correlations of exchange rates and prices. In countries with histories of persistent inflation, the link between 
Table 3. Correlation between Prices and the Current Exchange Rate, Selected Inflationary Episodes

\begin{tabular}{|c|c|c|c|c|}
\hline \multirow[b]{2}{*}{ Country and time period } & \multicolumn{3}{|c|}{ Consumer prices } & \multirow{2}{*}{$\begin{array}{c}\text { Average } \\
\text { inflation } \\
\text { rate (percent) }\end{array}$} \\
\hline & $\begin{array}{c}\text { Ahead two } \\
\text { months }\end{array}$ & Current & $\begin{array}{c}\text { Lagged } \\
\text { two months }\end{array}$ & \\
\hline \multicolumn{5}{|l|}{ Bolivia } \\
\hline 1980:1-1983:1 & 0.233 & 0.531 & 0.472 & $5.41^{\mathrm{a}}$ \\
\hline 1983:2-1986:2 & 0.870 & 0.997 & 0.864 & 25.71 \\
\hline \multicolumn{5}{|l|}{ Israel } \\
\hline 1980:1-1982:9 & 0.611 & 0.608 & 0.381 & $6.20^{\mathrm{a}}$ \\
\hline 1982:10-1985:7 & 0.840 & 0.999 & 0.839 & 11.48 \\
\hline \multicolumn{5}{|l|}{ Argentina } \\
\hline 1985:7-1989:1 & 0.878 & 0.993 & 0.866 & 10.07 \\
\hline 1989:1-1989:7 & 0.235 & 0.968 & 0.003 & 49.43 \\
\hline \multicolumn{5}{|l|}{ Brazil } \\
\hline 1960:1-1969: 12 & 0.945 & 0.988 & 0.936 & 1.29 \\
\hline 1980:1-1985:2 & 0.789 & 0.993 & 0.787 & 3.25 \\
\hline 1985:3-1990:6 & 0.709 & 0.987 & 0.626 & $16.88^{\mathrm{a}}$ \\
\hline
\end{tabular}

Source: Authors' own calculations and International Financial Statistics. The data are monthly, and prices are the consumer price indexes for each country.

a. The inflation rate is the average over the periods indicated, except where data were available: the first inflation figure for Bolivia is average from May 1980 to January 1983; the first figure for Israel is from October 1980 to September 1982; and the last figure for Brazil is from March 1985 to April 1990.

the dollar and domestic prices is well developed. An increase in the rate of inflation results in a shortening of the adjustment lags, mirrored by a tendency for the correlations to become centered on the contemporaneous value. By contrast, in countries without a history of exchange rate indexation, accelerating inflation leads to the development of indexation mechanisms, resulting in a uniform increase in correlations across leads and lags.

In table 3, we divide inflationary episodes into several parts and present the correlations between the current exchange rate and both current prices and prices with leads and lags. The data broadly support our hypothesis. For Brazil and Argentina, it is interesting to note that as inflation increases over time the correlation with leads and lags falls off sharply.

\section{Inflation and Price Adjustment}

An important aspect of pricing involves the basis on which adjustments are made. At moderate rates of inflation, adjustment will be based on past inflation. As inflation rises, the adjustment interval shrinks, though 
the inflation over the immediately preceding period still continues to be a reasonable predictor of the inflation immediately ahead.

Not surprisingly, information about inflation becomes more widely known and more current as inflation rises. Countries with monthly inflation rates of 20 or 30 percent routinely develop private, if not official, estimates of inflation rates on a weekly basis. But even weekly data obsolesce when inflation accelerates sharply, which may explain the ultimate shift to the dollar. Although the foreign exchange value of the dollar is quite unstable, it may still represent a better estimate of the general price level than a guess based on a narrow sample of current and previously reported prices. As one can imagine, several different variables are used when making price adjustment. The choice of variables depends on their past correlation with the general price level. If the correlation between the general price level and the dollar becomes more stable as inflation increases, signal extraction arguments would explain the increasing shift to the dollar as the best predictor of the general price level.

Some evidence of this phenomenon comes from the German experience in the 1920s. In regressions of current prices on the current exchange rate and lagged prices, in the early phase of German hyperinflation, the exchange rate did not carry significant information about the current price level beyond what was contained in lagged prices. After the breakdown of stability in the spring of 1922, however, the exchange rate became an increasingly important predictor of current prices. This evidence supports the idea that exchange rates ultimately become the basis of pricing.

If wage and retail price setters were to shift from using past inflation, perhaps on a monthly basis, to using the current exchange rate as a pricing guide, all lags would disappear. In combination with endogenous money, a totally unstable price level emerges. This catchup process explains the explosion in the price level and exchange rate that characterizes outright hyperinflation.

\section{Labor Market}

Juan Peron allegedly observed that when prices take the lift, wages cannot take the staircase. ${ }^{23}$ In the labor market, wage adjustments are

23. See Cavallo (1982). Peron's insight was already familiar to the New York Reform Club's Sound Currency Committee in the 1890s, see Reform Club (1896). 
usually based on formal or informal backward-looking indexation. This practice implies that when inflation accelerates, and the indexation interval does not decline nor are base wages raised, the average real wage declines. Reuben Kessel and Armen Alchian refer to this phenomenon as the wage-lag hypothesis and contest its existence. ${ }^{24}$ At issue is whether the real wage does decline in periods of accelerating inflation. And, if so, should the decline be attributed to a fall in the equilibrium real wage of a competitive labor market, or to features of wage setting that show insufficient flexibility in the face of accelerating, and perhaps incompletely anticipated, inflation?

The real minimum wage in Brazil, as shown in figure 3, provides an example. ${ }^{25}$ The nominal minimum wage is officially set on the basis of accumulated price increases, and applies to a significant part of the Brazilian labor market, including household workers and the informal sector. At the end of the 1970s, with annual inflation rates of 40-50 percent, nominal wages were adjusted only once a year. In 1979, the adjustment became semiannual (in May and November) even though the rate of inflation had risen to more than 200 percent. By 1986, the frequency of minimum wage adjustments became discretionary depending on which stabilization program, which invariably included wageprice controls, was in effect. From 1989 to the present, adjustments have been monthly or, at most, bimonthly. They continue to be backwardlooking, in that the adjustments equal the inflation that has accumulated since the last readjustment.

In every high inflation, there is pressure to adjust wages more frequently and more fully. The following quote from the German experience of 1919-24 characterizes the issues:

There was no lack of attempts to make the index number the sole determining factor in wage negotiations. The battle for the sliding wage scale began in Germany in the middle of 1919 , and never really quite stopped until the introduction of the system of gold wages. In the continued struggle to maintain the level of real wages, the workers showed a comprehensible preference for the system of complete automatic adaptation of wages. ... The employers almost unanimously refused the sliding scale, which they feared would lead to rapid and complete disaster, both monetary and economic. . . .26

24. Kessel and Alchian (1960).

25. The same pattern can be shown for wages in manufacturing. Accordingly the properties are not peculiar to administered wages. Pazos (1972) commented on this seesaw pattern of real wages.

26. Stizler (1924, p. 648). 
Figure 3. Brazil: Real Minimum Wage, 1977-90

Real minimum wage (index, January $1978=100$ )

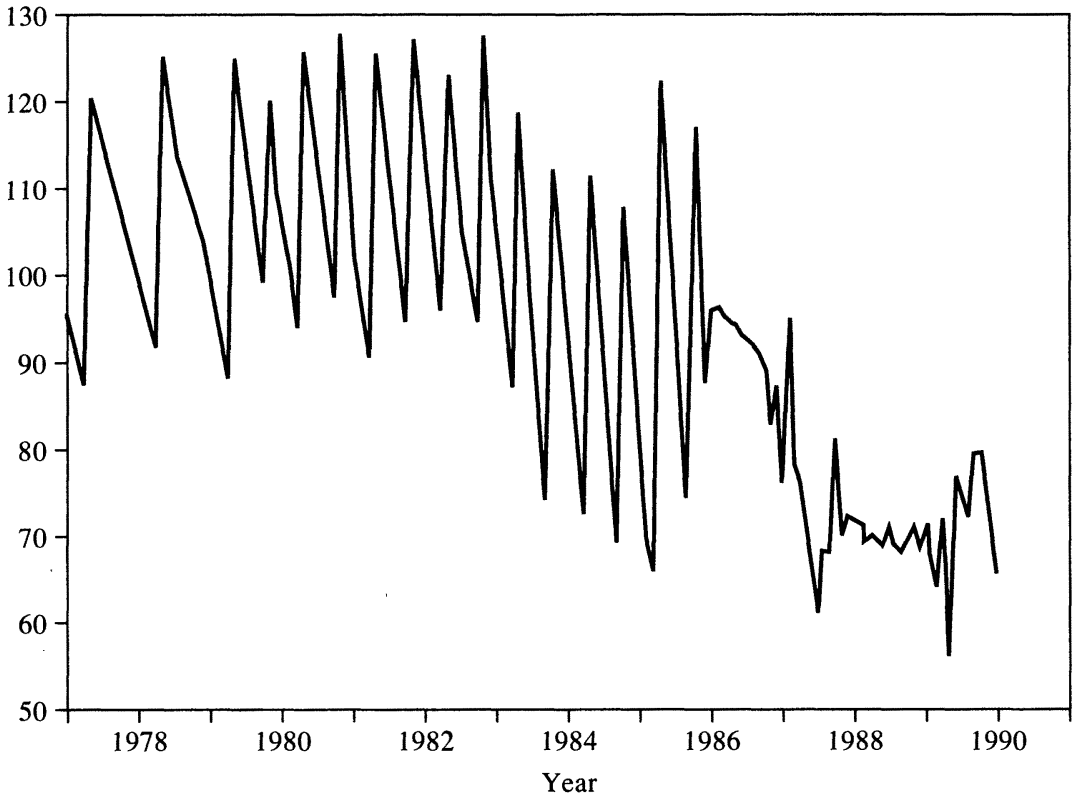

Source: Banco Central do Brasil Boletim Mensual and Conjuntura Economica, various issues.

In the extreme stages of the hyperinflation, indexation was complete. The only issue was whether the index number of Monday's prices, which was published on Wednesday, could still be useful for wage payments made later in the week. ${ }^{27}$

Why does the labor market accept so much variability in the real wage? Since much of the variability is anticipated, and since more frequent adjustments of money wages (as opposed to more frequent payments) do not have a resource cost beyond checking the latest inflation figure, there is a puzzle. With a given frequency of wage adjustments, higher inflation automatically depresses average real wages. As such, firms might be tempted to resist a shortening of the indexation interval. But why should workers not insist on higher base wages, and what stops firms from competing with more effective wage plans? While

27. See Stizler (1924, p. 655). 
the indexation interval does eventually shrink, suggesting some competition, it is surprisingly resistant when one considers the variation in real wages over the cycle and the handicaps that workers, relative to firms, face in accessing financial markets in order to smooth real wages.

More frequent adjustment, or prepayment of the next adjustment, resolves the labor unrest and the productivity problems that stem from the automatic decline of real wages under a fixed payment pattern. Once again, there is an important interaction between what the individual firm does and what the industry does. Firms find it hard to resist the industry pattern. When a few major firms accelerate the wage adjustment period, the entire industry does.

\section{The Payment Interval for Labor}

Not only is the indexation period unusually sticky, so is the payment period. At high inflation, the relatively infrequent payment of nonindexed wages means that workers lend to firms because the real wage they ultimately receive will have been eroded by inflation. Robert Barro has explored this issue and concludes that the adjustment of the frequency of payments is quite in line with the expectation of a theoretical model. ${ }^{28}$ In Barro's reformulation of the Baumol-Tobin money demand model, there is a fixed cost of making wage payments that leads, other things being equal, to infrequent payments. But the opportunity cost of holding money balances works in the opposite direction, arguing for frequent payments, more in line with the pattern of firms' receipts or workers' disbursements. Barro derives a formula for the optimal length of the payments period, $p$, measured in months,

$$
p=\sqrt{\lambda /\left(r^{*}+\pi\right)},
$$

where $\lambda$ is the fixed cost measured as a fraction of the monthly wage, and $r^{*}$ is the real interest rate. Table 4 shows illustrative calculations.

Barro considers the case where $\lambda=0.0025$ ( $\$ 1$ payment cost for a $\$ 400$ per month worker). For an inflation rate of 15 percent per month the model predicts a pattern of payments twice per week. In reality, we do not observe anything like that for economies with inflation rates around 15 percent. The frequency of payment lies between semimonthly

28. Barro (1970, 1972a). 
Table 4. Relationship between the Optimal Payment Period and the Rate of Inflation, for Selected Cost Ratios ${ }^{\mathrm{a}}$

Payment period (in months)

\begin{tabular}{lllll}
\hline $\begin{array}{c}\text { Cost } \\
\text { ratio } \\
(\lambda)\end{array}$ & \multicolumn{4}{c}{ Inflation per month } \\
\cline { 2 - 5 } & 0.03 & 0.15 & 0.30 & 0.50 \\
\hline 0.0025 & 0.250 & 0.125 & 0.090 & 0.070 \\
0.0050 & 0.354 & 0.177 & 0.127 & 0.099 \\
0.0075 & 0.433 & 0.217 & 0.156 & 0.121 \\
0.0100 & 0.500 & 0.250 & 0.180 & 0.140 \\
0.0500 & 1.119 & 0.559 & 0.402 & 0.313 \\
\hline
\end{tabular}

Source: Authors' own calculations based on Barro (1970), table 1.

a. Calculations are based on the equation $p=\sqrt{\lambda /\left(r^{*}+\pi\right)}$, where $r^{*}$, the real interest rate, is assumed to be 1 percent per month; $\lambda$, the cost ratio, is the fixed cost measured as a fraction of the monthly wage.

and monthly payments. To reach this pattern with the Barro formula, the transactions cost ratio, $\lambda$, would have to be 20 times larger than he assumes, amounting to 5 percent of the monthly wage.

The only point at which the model works well is when explaining the shift to almost daily, and even twice daily, payment when inflation reaches hundreds of percent per month. Even then the model must be qualified, as Steven Webb notes. The model does not at all accord with the evidence for inflation rates in the range of 10 to 30 percent per month. At those levels, payment patterns are much the same across a large range of inflation rates, even during periods of persistent high inflation. ${ }^{29}$

The basic flaw in the model would seem to be the assumption that firms, like workers, do not have access at low transactions costs to a stable asset in which to hold receipts. Experience has shown, however, that in countries with chronically high inflation financial markets adapt to provide stable assets, and when they do not, the dollar becomes an option. Accordingly, firms are reluctant to give up the real wage erosion that comes with infrequent payments. Were it not for efficiency wage arguments, firms would resist a speedup of payments when inflation rises. But even the efficiency wage argument is tempered by the fact that the firm's payment pattern depends on that of the industry.

The explanation for both the indexation and the payment period problems likely lies in the direction of Thomas Schelling's model of

29. Webb (1989, pp. 78-82). 
binary choices. If only a few firms adjust more frequently than the industry norm, nothing happens to the industry pattern. ${ }^{30}$ But when a critical number of firms do adjust wages, most others follow. Accordingly, a logistic pattern of adjustment emerges at the industry level. This acceleration in price adjustment in turn becomes a source of inflation, automatically accommodated by the increased money growth that results from the inflation-money linkage. The more the various components of the price level-the wage rate, public sector prices, and the exchange rate-are automatically indexed or adjusted and the more accommodating monetary policy is, the more automatic is the process of high and accelerating inflation.

\section{The Adjustment of Velocity}

In this section we focus on the "flight from money" as another driving force in an unstable inflationary process. As inflation increases, the public substitutes away from money toward other assets and toward goods. Adaptation in financial markets creates convenient alternatives to money, especially at higher rates of inflation. In the labor market, payment habits adapt and reduce real money demand. The combination of these forces leads to the dramatic rise in velocity, or demonetization, in high inflation economies. Figure 4 shows the steep decline in real balances that corresponded to the demonetization in the Bolivian hyperinflation.

\section{Financial Market Adaptation}

The flight from money may take three basic paths: a shift into foreign assets-notably dollar notes, domestic dollar deposits, or offshore accounts; a shift into interest-bearing domestic assets within the commercial banking system or in the money market; or a shift into real assets, whether they be goods inventories, equity investments, or real estate.

The distinction between movements along the real money demand schedule and shifts in real money demand helps explain the actual

30. Schelling (1978). 
Figure 4. Bolivia: Real Money, 1982-90a

Real money (index)

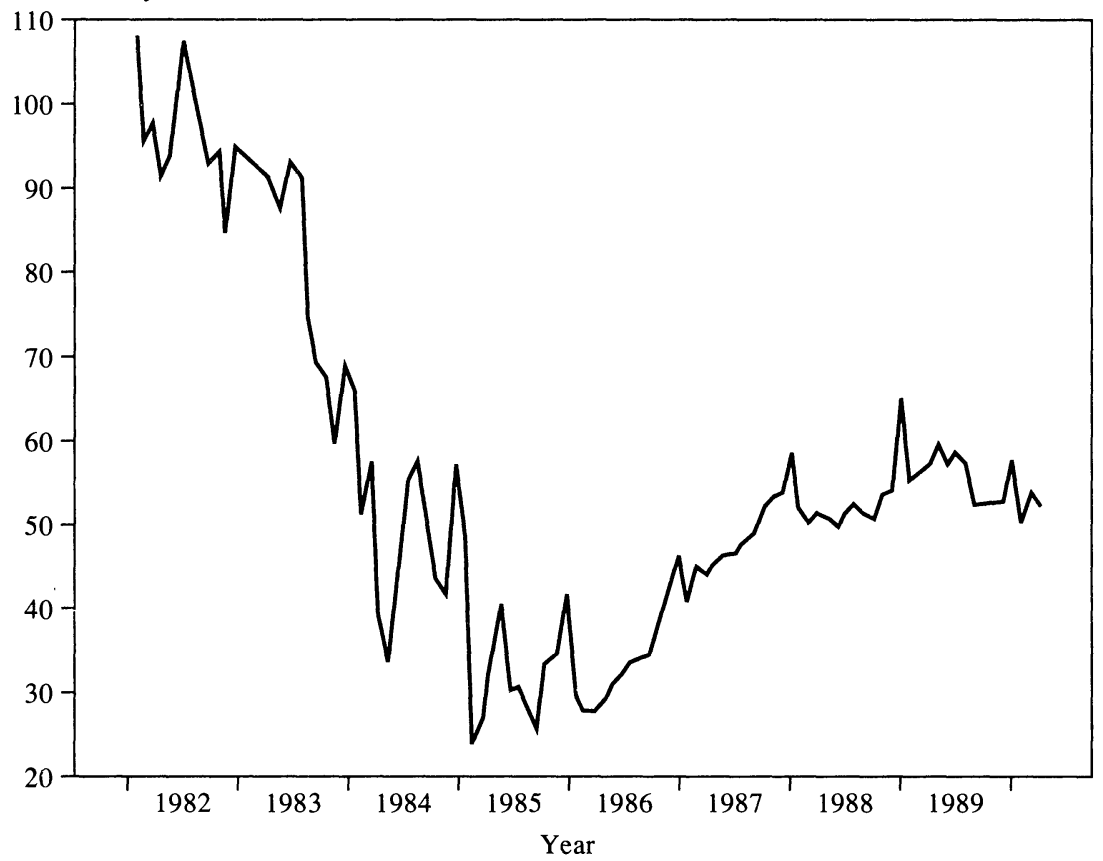

Source: Authors' own calculations using Muller and Associates, Statistical Review, various issues.

a. Real money is the nominal money supply in the local currency divided by the CPI $(1980=100)$.

dynamics of real balances during an inflation. The distinction may also explain why there are hysteresis effects. Once a new financial product is in use, it will continue to be used even if inflation declines. ${ }^{31}$

The response of real money demand to an increase in the cost of holding money is ordinarily thought of as a movement along a liquidity preference schedule. To some extent that is the case. But, we want to make the added point that there is financial adaptation. A black market for dollars develops; as vendors appear on every street corner, holding and using dollars becomes more convenient. When financial institutions introduce checkable, interest-bearing overnight deposits, holding noninterest bearing money becomes unnecessary. Financial institutions are

31. On the discussion of such a hysteresis effect, see Melnik (1990), Piterman (1988), and Ahumada (1989). 
Table 5. Brazil and Argentina: Income Velocity and Ratio of M1 to Broader Money Supplies, Selected Years

\begin{tabular}{|c|c|c|c|c|c|c|}
\hline \multirow[b]{3}{*}{ Year } & \multicolumn{3}{|c|}{ Brazil } & \multicolumn{3}{|c|}{ Argentina } \\
\hline & \multicolumn{2}{|c|}{ Velocities } & \multirow{2}{*}{$\begin{array}{l}\text { Ratio } \\
\text { M1/M4 }\end{array}$} & \multicolumn{2}{|c|}{ Velocities } & \multirow{2}{*}{$\begin{array}{l}\text { Ratio } \\
\text { MI/M3 }\end{array}$} \\
\hline & $M 1$ & M4 & & $M 1$ & M3 & \\
\hline 1976 & 8.0 & 3.5 & 0.44 & 11.9 & 7.4 & 0.62 \\
\hline 1980 & 10.7 & 4.4 & 0.41 & 14.0 & 4.4 & 0.31 \\
\hline 1984 & 22.2 & 3.4 & 0.15 & 21.5 & 7.1 & 0.33 \\
\hline 1988 & 34.6 & 3.2 & 0.09 & 24.4 & 6.0 & 0.25 \\
\hline 1989 & 45.5 & 3.6 & 0.08 & 27.8 & 7.1 & 0.26 \\
\hline
\end{tabular}

Source: Brazilian data for 1980-89 are from Central Bank of Brazil, Brazil Economic Program, June 1990, table 2.4; Brazilian data for 1976 are from Brazil Economic Program, June 1987, table 2.4. Argentine data for 1988-89 are from Fundacion Mediterranea, Suplemento Mensual Estadistico, August 1990; the 1976-84 data are from World Bank, Argentina: Reforms for Price Stability and Growth, August 1989, table 6.2.

not ready-made to accommodate the flight from money. In the short run, households may hold more real balances than they will after alternative vehicles become available or better known. In practice this will look like adjustment lags, but it also reflects the adjustment of financial institutions to the increased inflation.

Table 5 shows velocities in Brazil and Argentina. The data show the near total disappearance of M1 and the relative stability of the velocity of broader orders of the money supply. But even here there was adjustment because, in some periods, real interest rates were substantially negative.

The adjustment of M3 (or M4, depending on national institutions) reflects the extent to which financial markets can adapt to inflation and depreciation. Specifically, in a market where nominal interest rates substantially reflect inflation and depreciation, the velocity of M3 should be quite stable. By contrast, if interest rates are controlled, asset holders will substitute out of the financial system into dollars or real assets.

In Brazil, financial markets substantially adapted. As a result, the velocity of M1 rose more than in other countries, while that of M4 increased less. The sharp rise in the velocity of $\mathrm{M} 1$ reflects a well organized payment system by check (even for a lunch snack) drawn on overnight accounts. In Argentina, by contrast, the recurrent cycles of price explosions and freezes, without explicit indexation, drove asset holders out of the financial system and lead to a pervasive dollarization. ${ }^{32}$

32. See Ortiz (1983), Marquez (1987), Ramirez-Rojas (1985), and Calvo (1985) and the references found there. 


\section{Dynamics}

The dynamics of real money demand in response to an increase in inflation involve several steps. First, inflation must increase for a sufficiently long period and must be expected to remain high long enough for new financial services to be offered. Second, households and firms gradually adjust to these new products. Third, as households start adjusting, the new product is offered more pervasively and competitively, thus speeding up the response of money holders.

Once new financial products have been adopted, increases in the rate of inflation influence real money demand until a new threshold is reached where yet more liquid, interest-bearing assets are offered. This process converges either to dollarization or to an economy with most of the financial market represented by an interest-bearing overnight market.

A further influence on velocity, and hence on inflation dynamics, comes from adjustments in payment habits in goods and factor markets. In the goods market, the pervasive acceptance of checks drawn on the overnight market reduces transactions costs and cuts deeply into the demand for a real monetary base.

In the labor market, as observed in the inflationary experiences of the 1920 s and formalized by Barro in 1970, the frequency of wage disbursements responds to the cost of holding money between payments. For those in the labor force who hold only currency, an increased frequency of payments translates into an automatic rise in velocity. This effect is clearly at work in extreme inflation experiences, when payment becomes daily and agents even resort to barter.

\section{Indexed Money}

An important part of the dynamics of financial markets is the radical shortening of the maturities of public debt. In the absence of indexation, or of credible indexation, asset holders require either short-dated securities or high risk premiums. Governments respond by shortening the maturity of the debt. The more precarious the situation, the shorter the debt until the point where one-week debt is considered long term, and interest is credited daily in the overnight. ${ }^{33}$ That situation is obviously

33. In Brazil, for example, the government used to issue nominal three-month bills that had only a week left to maturity. Even these bills were subject to repurchase agreements so that the effective maturity of the debt was a day. 
quite volatile. As a result, funding crises threaten daily. Anytime the prospect of real depreciation emerges, real interest rates must become very positive to encourage asset holders to roll over their positions for yet another day. The shortening of maturities on financial assets implies that any distinction between money and debt is lost except in the sense that the demand for a monetary base almost vanishes and with it the scope for seigniorage disappears too.

When the government debt has shortened sufficiently, the stage is set for a nearly inflation-proof financial system. Financial institutions adapt by carrying both government debt as assets and interest-bearing, checkable deposits as liabilities. There may not even be a reserve requirement. Thus, the demand for a monetary base is sharply reduced.

The most intriguing aspect of this arrangement is the fact that money is effectively indexed. Since M1 will become a diminishingly small fraction of the money stock, and since the remainder carries interest rates that match inflation, money holdings are practically indexed. Thus, far from being in a situation where there is substantial seigniorage, the debt effectively becomes interest-bearing money and inflation is selfperpetuating unless the budget is balanced or the debt is frozen.

\section{A Simulation Exercise}

We now pull the various elements together in a simulation model based on microeconomic optimization. With endogenous pricing frequencies, endogenous velocity, and an endogenous money supply, the model has all the ingredients of a highly unstable economy. Disturbances in the budget lead easily to an explosive path for prices.

We combine a model of pricing under monopolistic competition with an endogenous money supply process, taking account of the feedback running from inflation to government finance and the individual consumption choices on the pricing side. ${ }^{34}$ The model, described in greater detail in the appendix, comprises three monopolistically competitive "sectors" made up of producers and consumers maximizing an intertemporal utility function defined over money and goods. Velocity is endogenous with respect to inflation. Individual producers and consumers face demand curves that depend upon the level of aggregate demand,

34. See Blanchard and Kiyotaki (1987). For an alternative approach see Calvo (1983). 
which depends on real balances, and relative prices. Solving the maximization problem (taking the optimal actions of competitors into account) yields optimal prices that are increasing in aggregate demand.

Each firm faces an idiosyncratic cost of changing prices. Actual prices are adjusted to their optimal level if the utility gain from an adjustment exceeds its cost. The model is closed by introducing the government budget constraint: the increase in the nominal money supply is passively determined by the seigniorage required to cover the deficit. Government expenditure is exogenous; real revenues suffer from the Tanzi effect, and decrease with the inflation rate.

To illustrate the model, consider the effects of a 1 percent increase in government expenditure, starting from the initial steady state characterized by a balanced budget and zero inflation. The resulting primary deficit is financed by money issue, which increases real demand at given prices. Eventually the divergence between actual and optimal price is sufficiently large for the first of our three sectors to adjust. That sector's price increase has two effects. It reduces the relative prices of the remaining two sectors and increases the growth rates of nominal and, if real revenues are sufficiently sensitive to the inflation rate, real money. Both effects increase the likelihood that the other sectors will adjust prices too.

With a small initial shock and small adjustment costs, the economy will shift to a new stationary equilibrium with positive inflation rates. If the initial shock is sufficiently large, no stationary equilibrium may be found. Similarly, if the eventual adjustment of the third sector is sufficiently large, it may reduce real revenues enough to push the economy into hyperinflation.

The model captures several characteristics of hyperinflation experiences.

-Multiple equilibria. With a balanced budget, no monetization occurs and the economy remains at a zero inflation equilibrium. For small deficits, the economy tends toward stationary equilibrium inflation paths. For large deficits, the feedback effects from the pricing rules to the budget deficit dominate, and the inflation solution eventually becomes nonstationary.

-Zigzag patterns of real prices. With differential adjustment costs, relative prices are characterized by periods of sustained decline, interspersed with one-time upward adjustments. 
-Choppy inflation rates. The optimal adjustment frequency differs across sectors as well as over time, due to dependence on the aggregate inflation rate. As a result, the overall inflation rate is highly variable. Periods of virtual price stability are interspersed with sudden bouts of rapid inflation..$^{35}$

- Hysteresis. A sufficiently large transitory increase in government expenditure can increase real balances enough to induce price adjustment by firms. The resulting inflation can shift the economy from an initial zero inflation to a new steady state with positive inflation, lower real tax receipts, and continued monetization of the primary deficit.

-Butterfly effects. In the presence of adjustment costs, the cumulative rather than the current deficit determines pricing behavior. A small deficit, maintained long enough, eventually triggers price adjustment. Thus, a period of apparent price tranquility may suddenly give way to hyperinflation.

Figure 5 presents simulation results that illustrate some of the above features. The simulation shows the response of an economy to shocks that take the form of modest, exogenous budget deficits. The first panel shows the inflation rate for an economy where the government's budget is subject to a large Tanzi effect. For several periods the government runs a small budget deficit and little happens. But, eventually the buildup in aggregate demand causes prices to be readjusted, which feeds back into the money creation process. In the end, the economy takes an unstable path with increasing inflation.

The second panel shows the evolution of the change in relative prices, as measured by a dissynchronization index. Again, we focus on an economy in which the government's budget is subject to a large Tanzi effect. The index is computed as the average of the absolute change in relative prices compared to the fastest adjusting sector of the economy. With zero inflation, relative prices are constant and the value of the index is zero. As inflation picks up, some sectors lag behind. The induced changes in relative prices increase the index. In the final stage of hyperinflation, not shown in the figure, there is a shift to exchange rate pricing and relative prices are once again aligned.

The last panel shows an alternative scenario with the budget deficit subject to a small Tanzi effect. The pattern of inflation is characterized

35. This feature results from the small number of agents in the model. 
Figure 5. Simulation of the Effects of a Budget Deficit
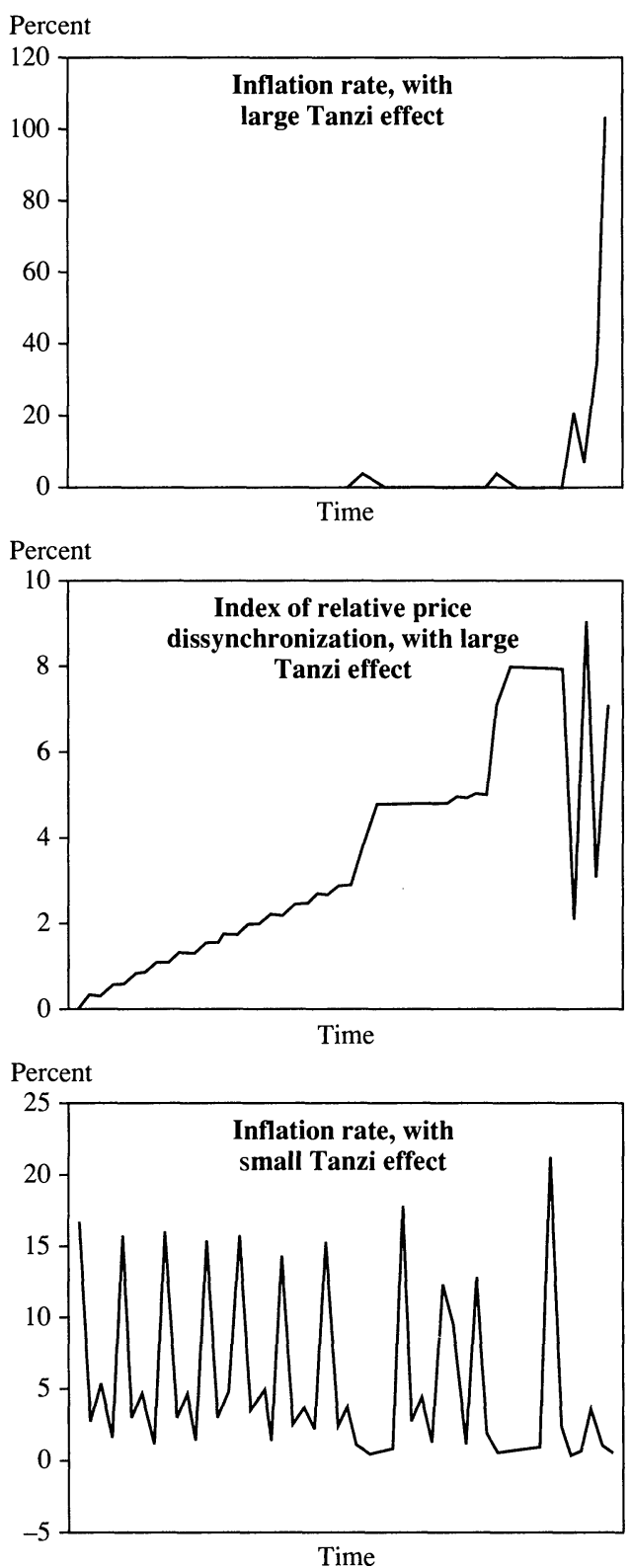

Source: Authors' own calculations. For the first two figures, the shock to government spending is 0.3 percent; for the third, it is 1.0 percent. 
by strong fluctuations as some sectors adjust at discrete intervals. Average inflation, however, is modest and does not explode.

\section{Open Economy Aspects}

Inflation dynamics are often discussed using the framework of a closed economy in which the exchange rate does not play a central role in the inflation process. This view is quite explicitly made by Cagan. Thomas Sargent and Neil Wallace also do not allow any special role for the exchange rate or for other aspects of an open economy. ${ }^{36}$ By contrast, much of the discussion in the 1920 s and more recently in the 1980 s focuses on whether the external sector does play a key role, if not the leading one. In fact, the debate between the balance of payments school and the quantity theory school turns on precisely this point. ${ }^{37}$

If the external sector and the exchange rate do play an independent role, depreciation and inflation cannot be fully correlated-that is, purchasing power parity must not hold. An easy measure of the extent to which this is the case is the behavior of the real exchange rate. Figure 6 shows the real exchange rate for Argentina. The large variations in the real exchange rate leave no doubt that an assumption of purchasing power parity is far from actual experience. The same picture emerges for any other high inflation country.

\section{Linkages to Money Creation}

The external sector directly affects the growth rate of money in several ways. First, the real exchange rate is a determinant of the real budget because the government has foreign exchange receipts (from exports) or foreign exchange outlays (from debt service), the value of which in domestic prices varies with the real exchange rate. Real exchange rate changes also affect the real revenue from ad valorem export or import taxes. Second, governments practice multiple exchange rates. As a result the budget deficit is affected by the differential between average buying and selling rates. Finally, external debt service shifts from

36. Sargent (1982); Sargent and Wallace (1973a).

37. See Bresciani-Turroni (1937), Graham (1930), Ellis (1934), Rist (1966), Robinson (1938), Polak (1943), Dornbusch (1987), and Montiel (1989). 
Figure 6. Argentina: Real Effective Exchange Rate, 1970-90

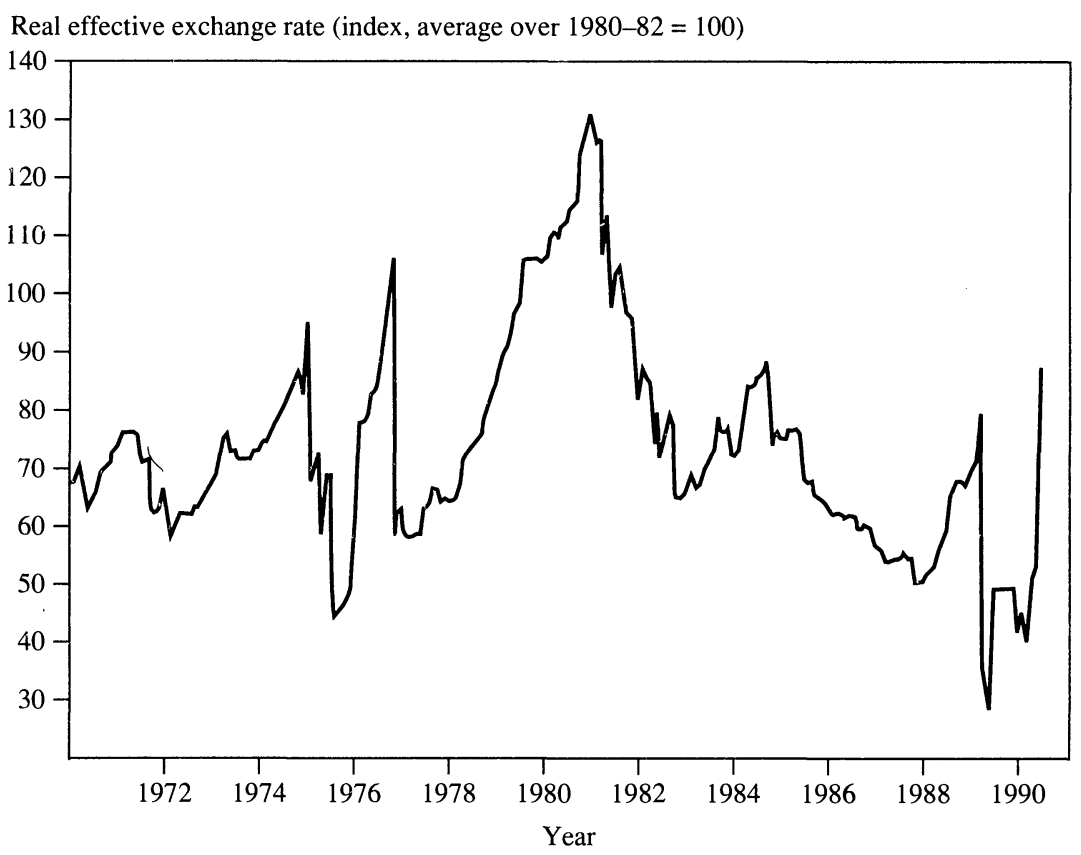

Source: Unpublished data from Morgan Guaranty Trust Company.

automatic financing through rolling over debt to domestic financing through creating money.

Consider again the equation defining money creation,

$$
\dot{M} / P Y=\theta+\lambda x+z,
$$

where $\theta$ now denotes the domestic deficit, $x$ the external public debt service, and $z$ the private sector's external balance; all these variables are expressed as a fraction of GNP. The term $\lambda$ is the fraction of debt service that is financed by domestic money creation. Arminio Fraga, Jeffrey Sachs and Juan Antonio Morales, and Rudiger Dornbusch and Juan Carlos de Pablo have argued that the sudden need to serve external debt, and the resulting domestic money creation, has been an initiating factor in the inflations of the 1980s. ${ }^{38}$

38. Fraga (1986); Sachs and Morales (1988); Dornbusch and de Pablo (1989). 
A real depreciation raises the real value of debt service, and hence leads to money creation. Similarly, if the government runs a noninterest deficit in foreign exchange, this will increase as a source of money creation in the case of real depreciation. The same is true for an acrossthe-board real depreciation under multiple exchange rates that involves buying rates below selling rates.

High inflation experiences tend to occur during wartime, but can also occur in the aftermath of disruptions that have a significant external dimension. External debt service plays a special role when there is a shift from external financing of debt service (and possibly even of the domestic deficit) to domestic financing. The domestic financing, if done by money creation, inevitably raises the rate of money creation and hence translates into higher inflation. In the $1920 \mathrm{~s}$, the argument was widely accepted that reparation payments created a double transfer problem, in the budget and in the balance of payments, that was responsible for the acceleration of German inflation. ${ }^{39}$ After 1982, debtor countries serviced their debts, at least partially, rather than relying on automatic rollover. In terms of equation 10 , making no paymentsneither principal nor interest-avoids any monetary financing of debt service. The shift to substantial debt service immediately increases the rate of money creation associated with a given noninterest deficit.

While external debt problems may lead to increased money creation and inflation, they do not always do so. Some heavily indebted countries have been able to avoid extreme inflation by using domestic debt finance. Table 6 compares low and high inflation countries. Both groups have approximately the same debt ratio and debt service burdens. Besides the difference in fiscal deficits, the groups differ in that 89 percent of the 29 high inflation countries have debt service problems, while only 27 percent of the low inflation countries experience debt problems. Thus high inflation appears to go hand-in-hand with debt service problems.

In countries where debt service causes an extreme inflation, reduction or abandonment of debt service, or of reparations in the case of the 1920 s, is pivotal to stabilization: it slows money creation, thus eliminating a driving force of high inflation. Sachs and Morales believe this was a key step in the successful Bolivian stabilization..$^{40}$

39. See German Foreign Office (1922) and Webb (1989).

40. Sachs and Morales (1988). 
Table 6. Debt and Inflation in Developing Countries, 1983-89a

Percent

\begin{tabular}{lcc}
\hline & $\begin{array}{c}\text { Low } \\
\text { inflation } \\
\text { countries }^{\mathrm{b}}\end{array}$ & $\begin{array}{c}\text { High } \\
\text { inflation } \\
\text { countries }^{\mathrm{b}}\end{array}$ \\
\hline Debt $^{\mathrm{c}}$ & 39.5 & 45.9 \\
Debt service $^{\mathrm{c}}$ & 7.3 & 5.8 \\
Fiscal deficit $^{\mathrm{c}}$ & 1.3 & 7.5 \\
Annual money growth & 12.0 & 187.8 \\
\hline
\end{tabular}

Source: International Monetary Fund, World Economic Outlook, May 1990, pp. 59 and 61.

a. The sample includes 88 net-debtor developing countries. All numbers are weighted averages over the period calculated with GDP weights.

b. Countries with less than 6 percent annual (CPI) inflation were classified as low inflation countries, while countries with more than 15 percent annual inflation were considered high inflation countries.

c. Debt, debt service, and fiscal deficit are expressed as percent of GNP.

The terms of trade also link the external sector and the budget. There may be a direct link if the government owns a major primary commodity operation, such as oil in Mexico. In that case, a deterioration in the terms of trade directly reduces government revenue and leads to financing problems. Even if the government does not directly own the operation, government revenue is still affected through taxes on profits and general taxation. A commodity boom helps the budget, a commodity depression hurts it.

The terms of trade linkage has played a key role in several high inflation countries. In Mexico, the terms of trade have declined by nearly a half since 1980, mostly a reflection of the decline in world oil prices. In Bolivia and Argentina, major terms of trade deterioration has significantly worsened the budgets. On the other hand, the terms of trade have, if anything, improved in some countries like Brazil.

\section{Asset Market Linkages}

In the asset market, the availability, legal or illegal, of external assets plays a central role in the inflation process. The alternative cost of holding domestic assets is given by the return on dollar assets, which includes interest plus currency depreciation. Even when foreign assets have to be held in the form of currency, depreciation is still the alternative cost of holding domestic nominal assets.

The opportunity to hold external assets, if only in the form of currency, 
significantly reduces the transactions costs to economic agents of the "flight from money." This ability makes real money demand more responsive to higher inflation in those economies where no domestic financial market exists. The effect is reinforced if foreign monies become acceptable and are routinely used as a means of payment. In that case even foreign assets carry the nonpecuniary returns associated with domestic currency.

Consider the case where external assets mostly take the form of noninterest-bearing currency or deposits, with a return equal to the rate of currency depreciation. Let $\psi$ denote the expected rate of depreciation and assume that velocity depends on the alternative cost of holding domestic rather than external assets: $V=\alpha+\beta \psi$. Now, anticipated real depreciation becomes an additional inflationary factor. Equation 5 is modified to read

$$
\pi=\frac{\alpha \theta+\beta(\psi-\pi)}{(1-\beta \theta)}
$$

The prospect of real depreciation, according to equation 11, raises velocity and hence raises the rate of money creation at each rate of inflation. Moreover, the availability of external assets tends to raise the value of $\alpha$ and possibly $\beta$ since foreign money is presumably more liquid and hence a better substitute for domestic money than goods.

\section{Depreciation and Inflation}

Another potential channel for external influence stems from a direct impact of exchange rate changes on the pricing process. ${ }^{41}$ This can occur because the exchange rate affects the price of imported inputs such as oil. Currency depreciation also raises the prices of import-competing goods and exportables, and can exert pressure on wages through the increased cost of living. This is particularly likely when a formal indexation mechanism exists.

An interaction between inflation and currency depreciation arises almost mechanically when there is explicit or implicit indexation of wages. In such a situation a real depreciation will be an automatic source of inflation acceleration. Several of the initial rises in inflation in the 1980s may be traced to this channel.

41. On this issue, see Dornbusch (1982) and Bruno and Fischer (1986). 
Consider a simple model of the wage-price sector. Current wage increases are based on lagged inflation and on activity, $y$. Current inflation is the weighted average of wage inflation and nominal exchange rate depreciation, $\psi$. In this setting, for a given level of activity or real demand, the acceleration of inflation will depend on the level of activity and the rate of real depreciation, $\psi-\pi$,

$$
\Delta \pi=\Phi(\psi-\pi)+\eta y .
$$

We have already seen that real exchange rates are not constant; accordingly, if formal or informal indexation is a significant part of the pricing process, real depreciation must lead to an acceleration of inflation, not only through potential budget effects but also through pricing directly. ${ }^{42}$

Under a managed exchange rate regime, the rate of currency depreciation is set officially. Real depreciation occurs when the government decides to improve external competitiveness. If the exchange rate is flexible, or if the black market exchange rate plays an important role in the inflation equation, we must consider the exchange rate to be an auction price that is determined in a forward-looking fashion. In this context, anticipation of budgetary problems can lead to a currency depreciation and acceleration of inflation even ahead of the actual deficits.

Table 7 explores the role of the real exchange rate by asking whether real currency depreciation is a significant determinant in inflation. The quarterly inflation rate is explained by lagged inflation, real depreciation, and an incomes policy dummy. There is no claim that the specification should be the same for all countries. Indexation arrangements, adjustment in public sector prices, and the prevailing level of slack in the economy, which depends in part on the extent of monetary accommodation, all play a role in shaping both the timing and effect of a real depreciation. The basic point is that real depreciation acts as a shock that will, over time, raise the rate of inflation. ${ }^{43}$

42. In Brazil, for example, full backward indexation was mandatory in the early 1980 s.

43. We concentrate here on exchange rate shocks. Major changes in public sector prices also have the effect of a sharp increase in inflation. An example would be the Peruvian adjustment program in the fall of 1988. Public sector price adjustments tend to come together with exchange rate correction and hence the separate role of each of these shocks may be difficult to establish. 
Table 7. Effect of Real Depreciation on Inflation, Israel and Mexico, 1971-89a

\begin{tabular}{|c|c|c|c|c|c|}
\hline \multirow[b]{2}{*}{ Country } & \multicolumn{2}{|c|}{ Inflation } & \multirow{2}{*}{$\begin{array}{c}\text { Incomes } \\
\text { policy }^{\mathrm{b}}\end{array}$} & \multirow{2}{*}{$\begin{array}{c}\text { Real } \\
\text { depreciation }\end{array}$} & \multirow[b]{2}{*}{$R^{2}$} \\
\hline & One lag & Two lags & & & \\
\hline Israel & $\begin{array}{c}0.52 \\
(5.0)\end{array}$ & $\begin{array}{r}0.37 \\
(3.6)\end{array}$ & $\begin{array}{r}-0.28 \\
(2.0)\end{array}$ & $\begin{array}{c}0.33 \\
(2.1)\end{array}$ & 0.66 \\
\hline Mexico $^{d}$ & $\begin{array}{r}0.89 \\
(15.6)\end{array}$ & $\ldots$ & $\begin{array}{c}-23.6 \\
(3.4)\end{array}$ & $\begin{array}{c}0.16 \\
(2.2)\end{array}$ & 0.73 \\
\hline
\end{tabular}

Source: Authors' own calculations. The numbers in parentheses are $t$-statistics.

a. Inflation is regressed on lagged inflation, incomes policy dummy, and real depreciation using quarterly data. The value of the constant is not reported.

b. A dummy variable is used for incomes policy. For the first four quarters of an incomes policy the variable equals one. At all other times, the variable equals zero. In Israel, the incomes policy variable equals one from the third quarter of 1985 to the first quarter of 1986; in Mexico, from the second quarter of 1988 to the second quarter of 1989. When the incomes policy variable enters the equation with a value of one, the dummy takes on the value of lagged inflation.

c. Real depreciation for Israel is one-quarter lagged depreciation; for Mexico, a four-quarter polynomial distributed lag.

d. The equation for Mexico is corrected for serial correlation.

\section{Granger Tests}

Thus far, we have considered the possibility that shocks to the exchange rate, just as much as shocks to public sector prices or the budget, could be the dominant factor in propagating inflation. To explore the role of exchange rates further, we now consider Granger causality and structural vector autoregression (VAR) tests. We believe that the body of evidence shows, in a number of different and complementary ways, that exchange rates play a key and independent role in the inflation process.

If, from Granger causality tests, exchange rates can be shown to affect money and prices, it would suggest that many earlier tests that disregarded the exchange rate were misspecified. Specifically, Granger causality running from exchange rates to inflation and money growth would support the balance of payments view, which argues for this direction of causation.

In table 8 we report the chi-squared test statistic on whether each variable is significant when added to a VAR regression of the other two variables in the table. ${ }^{44}$ Three lags were used uniformly. Consider the

44. As Sims, Stock, and Watson (1990) point out, the statistical interpretation of causality tests between (co-)integrated series depends on the precise form of nonstationarity in the data. Our interest here lies only in the relative importance of the exchange rate in the trivariate system. 
Table 8. Causality Tests on the Exchange Rate, Money, and Prices in Selected High Inflation Countries ${ }^{\mathrm{a}}$

\begin{tabular}{lccc}
\hline & \multicolumn{3}{c}{ Exchange } \\
Country & Money & rate & Prices \\
\hline Argentina & 8.1 & 39.7 & 15.3 \\
Bolivia & 18.7 & 19.1 & 5.7 \\
Brazil & 3.3 & 9.7 & 5.9 \\
Peru & 8.4 & 3.7 & 12.1 \\
Yugoslavia & 10.7 & 9.0 & 1.8 \\
\hline
\end{tabular}

Source: Authors' own calculations.

a. The table reports the chi-squared test statistic on the joint exclusion of each variable from a VAR regression of the other two variables. The values should be compared to the chi-squared critical values at the following levels: 10 percent level, $10.64 ; 5$ percent level, $12.59 ; 1$ percent level, 16.81 .

middle column that reports the significance test of the exchange rate as an extra variable in a system already composed of money and prices. Clearly the exchange rate belongs in the system as much as money and prices do.

\section{Structural VARs}

Structural VAR estimation provides an alternative methodology for studying the effect of the exchange rate on the inflationary process. Using this technique, we are able to decompose the variance in the inflation series into the components due to innovations in alternative "causal" variables.

Peter Montiel has used VAR estimation to analyze hyperinflation episodes. He attempts to discriminate between the fiscal view and the balance of payments view; he concludes in favor of the latter. While Montiel uses ordering assumptions to determine the relative contribution of the causal variables, we follow Olivier Blanchard and Danny Quah by employing restrictions derived from economic theory. ${ }^{45}$

We restrict our attention to three variables: inflation, the real exchange rate, and the real deficit, which is proxied by the ratio of base money

45. Both approaches have their drawbacks. While ordering assumptions are essentially arbitrary, our results depend critically on the correctness of the economic restrictions we impose. See Montiel (1989) and Blanchard and Quah (1989). 
creation to prices. ${ }^{46}$ Identification of the system requires three restrictions. We assume that, in the long run, innovations in neither the budget nor the inflation rate affect the real exchange rate. In addition, we assume that, in the short run, shocks to the deficit affect the real exchange rate with a lag.

The first two restrictions derive from the long-run dependence of the real exchange rate on real factors. The last restriction is based on the fact that money demand is a function of inflation and not of the deficit. Imposing these three restrictions, we can compute the structural impulse response functions.

The impulse response functions yield estimates of the variance decomposed by the percentage of the $k$-period forecast error that is explained by innovations to the three series. Table 9 presents the results for Argentina.

The table shows that the budget deficit reacts passively to inflation and exchange rate shocks. The independent contribution of the deficit to the inflation rate is almost negligible. These results strongly suggest that the endogeneity of the deficit is crucial in understanding the inflationary process.

Neither shocks to the inflation rate nor shocks to the deficit exert substantial influence on the real exchange rate. The real exchange rate, however, influences both inflation and the deficit, supporting the view that the exchange rate constitutes a crucial element, and not a sideshow, of the inflationary process.

Table 10 extends the evidence on the variance in inflation to other countries. The first panel provides strong support for the importance of the exchange rate in determining the inflationary process. The second panel suggests that the effect of innovations to the budget deficit differs substantially across countries. While in Argentina and Brazil the deficit was basically endogenous to the inflation process, it was an important driving force in Bolivia and Mexico. Finally the third panel illustrates how inflation feeds on itself as institutions adapt to the new environment.

46. All variables were transformed into stationary series. If the variables are cointegrated in the levels, the moving average representation is not invertible. To rule out this case, we tested for and rejected co-integration. We approximate the deficit by seigniorage collection except in the case of Argentina where we use the change in the real claims on the public sector. 
Table 9. Argentina: Decomposition of the Variance among the Exchange Rate, Deficit, and Inflation, 1982-89

Percent

\begin{tabular}{lcccc}
\hline & & \multicolumn{3}{c}{ Innovations in } \\
\cline { 3 - 5 } Variable & Months in forecast & $\begin{array}{c}\text { Real } \\
\text { exchange } \\
\text { rate }\end{array}$ & $\begin{array}{c}\text { Deficit } \\
\text { proxy }\end{array}$ & Inflation \\
\hline Inflation & 1 & 26.7 & 1.3 & 71.9 \\
& 10 & 28.8 & 3.1 & 68.0 \\
& 24 & 25.5 & 3.0 & 71.4 \\
Real exchange rate & 50 & 24.6 & 3.0 & 72.3 \\
& 1 & 83.6 & 0.0 & 16.3 \\
& 10 & 83.0 & 1.0 & 15.9 \\
Deficit proxy & 24 & 87.9 & 0.7 & 11.3 \\
& 50 & 92.5 & 0.5 & 7.0 \\
& 1 & 4.8 & 73.3 & 21.7 \\
& 10 & 33.7 & 41.3 & 24.9 \\
& 24 & 33.3 & 42.1 & 24.4 \\
& 50 & 43.0 & 22.7 \\
\hline
\end{tabular}

Source: Authors' own calculations. The table gives the results from impulse response functions that yield estimates of the variance decomposed by the percentage of the $k$-period forecast error that is explained by innovations to the three series.

a. The real deficit is proxied by the ratio of the change in real claims on the private sector to the price level.

Argentina and Brazil show the highest feedback effects, Bolivia and Mexico the lowest.

\section{Summary}

So far, we have identified several elements of the high inflation process: endogenous money, endogenous changes in pricing patterns, financial adaptation that accommodates the economizing on real balances, as well as causal movements in exchange rates. These elements combine to make inflation explosive.

As the general price level rises, inertia in price and wage adjustments and resistance to deficit finance disappear throughout the economy. As a result, inflation accelerates. This process is not an overnight phenomenon nor a common occurrence. But in countries with chronically high inflation, a shock to the budget or real exchange rate can trigger the process; if that occurs, gradual policy adjustment will not be enough to bring inflation under control. In fact, after an extreme inflation experience, the ability to hold inflation at 5 or 10 percent per month will be 
Table 10. Decomposition of the Variance in Inflation in Selected Countries

Percent

\begin{tabular}{lrrrr}
\hline \multirow{2}{*}{$\begin{array}{l}\text { Variable, country, and } \\
\text { time period }\end{array}$} & \multicolumn{4}{c}{ Months in forecast } \\
\cline { 2 - 4 } Due to real exchange rate & 1 & 10 & 24 & 50 \\
Argentina (1982-89) & 26.7 & 28.8 & 25.5 & 24.6 \\
Brazil (1975-90) & 45.1 & 23.0 & 18.7 & 17.1 \\
Brazil (1982-90) & 47.4 & 21.7 & 16.8 & 14.8 \\
Peru (1985-90) & 0.7 & 16.8 & 24.2 & 27.1 \\
Bolivia (1982-86) & 46.3 & 12.5 & 6.7 & 3.8 \\
Mexico (1975-87) & 28.1 & 39.3 & 41.5 & 42.3 \\
Mexico (1982-87) & 45.7 & 39.0 & 40.4 & 41.0 \\
Due to deficit proxy & & & & \\
Argentina (1982-89) & 1.3 & 3.1 & 3.0 & 3.0 \\
Brazil (1975-90) & 6.1 & 3.9 & 3.6 & 3.5 \\
Brazil (1982-90) & 10.1 & 7.3 & 7.0 & 6.9 \\
Peru (1985-90) & 27.2 & 25.6 & 23.7 & 23.0 \\
Bolivia (1982-86) & 31.9 & 51.6 & 58.3 & 61.6 \\
Mexico (1975-87) & 30.0 & 38.2 & 38.7 & 39.0 \\
Mexico (1982-87) & 12.0 & 50.6 & 53.3 & 54.4 \\
Due to inflation & & & & \\
Argentina (1982-89) & 71.9 & 68.0 & 71.4 & 72.3 \\
Brazil (1975-90) & 48.7 & 73.0 & 77.6 & 79.4 \\
Brazil (1982-90) & 42.4 & 70.9 & 76.1 & 78.2 \\
Peru (1985-90) & 72.0 & 57.5 & 52.0 & 49.7 \\
Bolivia (1982-86) & 21.7 & 35.8 & 34.8 & 34.4 \\
Mexico (1975-87) & 41.8 & 22.4 & 19.6 & 18.5 \\
Mexico (1982-87) & 42.2 & 10.3 & 6.1 & 4.5 \\
\hline
\end{tabular}

Source: Authors' own calculations. The table gives the results from impulse response functions, which give the percent of the $k$-period forecast error that can be explained by innovations to the series.

a. The deficit is proxied by the ratio of the change in base money to the price level, except in Argentina, where the proxy is the ratio of the change in the real claims on the public sector to the price level.

totally lost. Hysteresis effects weaken the economy's resistance to shocks and accelerate the responses to bad news, making the economy extremely vulnerable to inflationary shocks. Extremely low inflation may then be the only stable option.

Charles Kindleberger notes, "The fact that the French franc is weak when the Chamber of Deputies is sitting or when an unbalanced budget is announced is due to the fact that the French public fears uncontrolled inflation and begins to export capital." ${ }^{47}$ To some extent, expectations of inflation are self-fulfilling, given the link between real depreciation

47. Kindleberger (1937, p. 106). 
and inflation on the one hand, and between inflation and money growth on the other. ${ }^{48}$

Thus, Cagan quite explicitly rejects the view that exchange rates can play a central role. ${ }^{49}$ The evidence offered here suggests that exchange rates play a causal role in hyperinflations. The high inflation process can create such fragility in the economy that a collapse of the exchange rate may well trigger explosive inflation. Of course, a collapse of the exchange rate must ultimately be linked to changes in fundamentals, whether they be reparations, debt service, or capital flight..$^{50}$

\section{Three Stabilizations}

In this section we briefly report key facts of the stabilization programs in Israel, Bolivia, and Argentina. While the first two succeeded, the third is a textbook example of failed adjustment and lack of credibility. These cases provide background for the discussion of conceptual issues that follows.

\section{Israel}

Inflation in Israel escalated from an average annual rate of 60 percent in $1975-80$ to a nearly 200 percent average annual rate in $1980-85$. By early 1985 , following the breakdown of a number of stabilization efforts involving wage agreements, inflation reached 28 percent per month. A coalition government-with substantial U.S. prodding and financial backing-developed a strikingly successful stabilization program. ${ }^{51}$ Data for Israel are reported in table 11.

The Israeli stabilization program had four characteristics. First, fiscal

48. The debate between Friedman (1956) and Nurkse (1944) is pertinent here, as is Polak's (1943) explanation of European depreciation. In the French "psychological theory" of the exchanges, Aftalion (1948) paid attention to expectations-driven exchange rates.

49. He observes (1956, pp. 90-91, fn. 41): "To my knowledge no one has argued that depreciation of the foreign-exchange rate is sufficient to explain hyperinflations, but it is often considered to be a causal factor. The attempts to find statistical confirmation of this view are inadequate and unconvincing."

50. See Krugman (1979), Obstfeld (1984), and van Wijnbergen (1988) for models of speculative attack on unsustainable exchange rate regimes.

51. See Bruno (1989), Bruno and Piterman (1988), and Bruno and Meridor (1990). 
Table 11. Israel's Stabilization, 1984-89

Percent

\begin{tabular}{lrrrrrr}
\hline & 1984 & 1985 & 1986 & 1987 & 1988 & 1989 \\
\hline Inflation rate & 374 & 305 & 48 & 20 & 16 & 20 \\
Growth rate & 2.4 & 3.6 & 3.3 & 7.1 & 1.8 & 1.4 \\
Deficit $^{\mathrm{a}}$ & 10.4 & 2.6 & -1.9 & 1.3 & 4.6 & 4.7 \\
Terms of trade index $^{\mathrm{b}}$ & 99 & 113 & 105 & 101 & 91 & 93 \\
Real wage index $^{\mathrm{c}}$ & 89 & 85 & 96 & 105 & 109 & 107 \\
Real interest rate $^{\mathrm{d}}$ & $\ldots$ & 100 & 33 & 39 & 25 & 15 \\
\hline
\end{tabular}

Sources: Bank of Israel, Bruno and Meridor (1990), and the International Monetary Fund.

a. The deficit is expressed as a percent of GNP.

b. The terms of trade are defined as the relative price of foreign goods, taking April $1986=100$.

c. For the real wage index, April $1986=100$.

d. The real interest rate is the average short-term rate.

policy was tightened substantially. The budget deficit was cut dramatically by abandoning high cost investment projects, eliminating subsidies, and raising tax collection. In 1980-84, net tax revenue had averaged 21.8 percent of GNP; by 1985-87, it had increased to 30.7 percent.

Second, tripartite wage agreements supported the shift to a low rate of inflation. ${ }^{52}$ Third, the exchange rate was adjusted and kept fixed for more than a year. Fourth, the United States provided financial backing on the order of $\$ 1.5$ billion, or nearly 4 percent of Israeli GNP. Although never tapped, this reserve helped sustain confidence in the program.

The results of the program were immediate disinflation, a 20 percent rise in real wages, a real appreciation in the currency, and high real interest rates. The stabilization is credited with significant real growth in the succeeding two years.

By 1989, however, the success of the stabilization program was being called into question. Growth had by then slowed down to moderate levels, and inflation had settled at 15-20 percent, too high for comfort and too low to warrant an all-out attack. Could disinflation have been more successful? Could growth have lasted longer if the incomes policy had not been used? Should the exchange rate have been held at fixed levels at the cost of overvaluation?

The 1988-90 stagnation may, however, be overly ascribed to the 1985 stabilization. The stagnation may, in fact, be the product of an extraordinarily overregulated economy.

52. See Artstein and Sussman (1990) for detailed discussion of the role of wage agreements in the stabilization. 


\section{Bolivia}

Bolivia was drawn into a hyperinflation by terms of trade shocks and increasing difficulty in servicing external debt, which resulted from credit rationing in world capital markets. Vast budget deficits were financed by money creation, and inflation accelerated dramatically to reach record levels by mid-1985. Stabilization was achieved through uncompromising control of the budget and pervasive liberalization of trade and payments, wages, and prices. Some data on Bolivia are presented in table 12 .

A key step in getting the budget under control, which was urged by their foreign adviser, was the suspension of external debt service..$^{53}$ This single move substantially reduced financing requirements and helped limit cuts in the noninterest budget. Moreover, foreign resources, mostly in the form of aid, were able to finance the residual budget deficit. Accordingly, money creation was brought decisively under control.

Real tax revenue rose threefold within a year and fourfold between 1984 and 1989 ! Seigniorage declined sharply; what seigniorage remained primarily reflected remonetization rather than deficit finance. Credit to the public sector declined from 71 percent of M2 in 1984 to 16 percent in 1989. The continuing overall deficit was substantially financed from abroad. Foreign exchange transactions were fully liberalized, and the exchange rate was determined at auction. With greater financial stability and a resumption of market mechanisms, output recovered somewhat, though it remained below its 1980 level..$^{54}$

Just as in Israel, however, inflation now seems stuck in the double digits. This has occurred even though monetary policy has been decidedly orthodox since 1985 . The financial system never returned to a local currency habitat. In fact, Bolivia seems to be moving increasingly away from it. The gross investment rate continues to be exceptionally low10 percent of GNP in 1986-89 and not rising. Whether the low investment level reflects a lack of confidence or a lack of opportunity is open to question.

53. See Sachs (1987), Morales (1988, 1989), Morales and Sachs (1990), and Pastor (1990). An experience with high inflation in the 1950s, though not as extreme, and a very similar stabilization program are reported in Eder (1968).

54. The fact that output did not return to the level of 1980 is explained in part by a strong adverse terms of trade shock in the period. When adjusted for population growth, real income in 1989 was 10 percent below the 1984 level and 25 percent below that of 1980 . 
Table 12. Bolivia's Stabilization, 1984-89

Percent

\begin{tabular}{lrrrrrr}
\hline & 1984 & 1985 & 1986 & 1987 & 1988 & 1989 \\
\hline Inflation rate & 1281 & 11750 & 276 & 15 & 16 & 15 \\
Growth rate & -0.3 & -0.2 & -2.9 & 2.2 & 2.7 & 2.5 \\
Deficit $^{\mathrm{a}}$ & 26.5 & 10.8 & 3.0 & 8.2 & 7.5 & $\ldots$ \\
Seigniorage $^{\mathrm{a}}$ & 15.1 & 8.4 & 2.2 & 2.1 & 2.8 & 2.2 \\
Terms of trade index $^{\mathrm{b}}$ & 100 & 94 & 85 & 69 & 62 & $\ldots$ \\
Real interest rate $^{\mathrm{c}}$ & -89 & -96 & 0 & 29 & 15 & 20 \\
\hline
\end{tabular}

Sources: Banco Central de Bolivia, Morales (1990), and the International Monetary Fund.

a. The deficit and seigniorage are expressed as a percent of GNP.

b. The terms of trade are defined as the relative price of foreign goods when 1984 is taken as 100 .

c. The real interest rate is the lending rate.

\section{Argentina}

Argentina never stabilized, though there was no shortage of programs. ${ }^{55}$ Starting with the Austral plan, a new one was launched at least once a year. But they all failed because fiscal policy never decisively changed. Deficits always reemerged and were financed by money creation, money that nobody wanted to hold. As a result, the plans relied almost exclusively on incomes policy and exchange rate policy. In the late stages, they relied on unsustainably high real exchange rates. Each program led to a collapse, after which a new program was inaugurated. In the aftermath of successive stabilization attempts, inflation would reach still higher levels, and adaptation to high inflation would become more advanced. Some data on the Argentine experience are presented in table 13 .

The contrast between the experience of Argentina and those of Israel and Bolivia is striking. The decline in real wages and the cumulative and continuing decline in real income, which resulted from a progressive destruction of the productive sector, add up to a very negative verdict on economic policymaking in the 1980 s, particularly since 1985 when recurrent stabilization efforts were made. Variability in real exchange rates, real wages, and real interest rates has been exceptionally high in Argentina. But the degree of damage has been most evident in the cumulative experience: per capita output is below its level in the 1970s, net investment has been negative for years, and the real return on an investment in the Argentine financial system has been, on average, (1988).

55. See Dornbusch and de Pablo (1989), Heyman (1990), and Canavese and Di Tella 
Table 13. Argentina's Failed Stabilization, 1984-89

Percent

\begin{tabular}{lrrrrrr}
\hline & 1984 & 1985 & 1986 & 1987 & 1988 & 1989 \\
\hline Inflation rate & 627 & 672 & 90 & 131 & 343 & 3079 \\
Growth rate & 2.6 & -4.5 & 5.6 & 2.2 & -2.7 & -4.6 \\
Budget $^{\mathrm{a}}$ & 11.2 & 9.9 & 5.4 & 8.1 & 8.5 & 10.3 \\
Real wage index $^{\mathrm{b}}$ & 100 & 84 & 83 & 79 & 74 & 70 \\
\hline
\end{tabular}

Sources: Banco Central de Argentina, Indicadores de Coyuntura and the International Monetary Fund.

a. The budget is the domestically financed budget as a percent of GNP.

b. For the real wage index, $1986=100$.

severely negative. One Austral deposited in 1983, with interest reinvested, would have declined in real terms to only 2 percent of its initial value by early 1990 .

\section{Stabilization Issues}

The endogeneity of the money supply, financial adaptation, and pricing all contribute to the process of explosive inflation. To end this inflationary process, a government must radically change the money supply process. When money becomes exogenous, inflation will eventually end. Sargent emphasized this point.

The essential measures that ended hyperinflation in each of Germany, Austria, Hungary and Poland were, first, the creation of an independent central bank that was legally committed to refuse the government's demand for additional unsecured credit and, second, a simultaneous alteration in the fiscal policy regime. These measures were interrelated and coordinated. They had the effect of binding the government to place its debt with private parties and foreign governments which would value that debt according to whether it was backed by sufficiently large prospective taxes relative to public expenditures. In each case that we have studied, once it became widely understood that the government would not rely on the central bank for its finances, the inflation terminated and the exchanges stabilized. ${ }^{56}$

Even within this framework, questions remain and important choices must be made. Does stabilization mean recession? When is the best time to stop inflation? Should incomes policy be a part of the stabilization? What nominal anchor should the government choose?

56. Sargent (1982, p. 89). 
The answers to these questions must involve wider issues of political economy and the role of credibility in promoting low-cost stabilization. Beyond the theoretical arguments, there is now a body of evidence from the experiments of 1980 s as well as the 1920s.

\section{Stabilization and Activity}

Stabilization suggests fiscal austerity, even recession. But that is not necessarily the case. Sargent argues on rational expectations grounds that price flexibility would prevent persistent effects on real output. ${ }^{57}$ Our argument is quite different. In a situation of extreme inflation, fiscal stabilization should be considered good news rather than a harbinger of recession. ${ }^{58}$ In the special case where external transfers are suspended as part of the reforms, the presumption of good news is even stronger.

In a situation of extreme inflation, neither external nor internal debt financing of the government is available. Current inflation taxes, negative real interest rates on assets, and payments arrears finance the government. Stabilization involves a shift away from the inflation tax toward normal taxation, subsidy cuts, and expenditure reduction. Inflation taxes are just as much current taxes as are income taxes; stabilization does not involve shifting taxes over time, as is the case with debt finance. As a result, except for distributional effects, real demand should not change. This is not a consequence of Ricardian equivalence, but rather an implication of the shift from an inflation tax to regular taxation. ${ }^{59}$ Moreover, since extreme inflation is highly distortionary, the shift to normal taxation raises economywide productivity. ${ }^{60}$

A push toward recession could come from the demand-side effects of redistribution that accompany the stabilization program. But, on balance, the distributional effects seem to run in the direction of an expansion: inflation is a highly regressive tax, so stabilization may

57. Sargent (1982). See Wicker (1986) for evidence to the contrary, in the case of Austria, and the discussion in Eichengreen (1986).

58. See, for example, Drazen and Helpman (1988) and Liviatan (1988).

59. We differ here squarely from Barro (1990), who argues that the evidence from Israel's stabilization-a program that included increased public saving and reduced private saving-represents a textbook case of Ricardian equivalence.

60. In addition, there may be effects on real investment. These will depend in part on the extent to which real assets have been used as an inflation hedge. Other things being equal, stability promotes investment. 
actually raise demand. But if the correction of the budget deficit eliminates subsidies on food, transport, and the like, the net change for lowincome families may be minor.

However, stabilization may reduce demand in two ways. First, it may trim public sector employment. While in the long run the corresponding reduction in taxation creates profit opportunities that translate into higher employment, in the short run jobs are lost and this cuts into spending. Second, the financial sector also loses jobs. This sector expands in a high inflation period and takes a dramatic downturn when stabilization occurs, which may account for some increased short-run unemployment.

Stabilization may well raise aggregate demand through an increase in the purchasing power of wages. This has been the case in Israel and Bolivia. Gains in the real wage can be explained by the increase in the economies' productivity that results from increased stability. Also, in extreme inflation, firms protect themselves by charging high prices "in dollars," which correspondingly reduces real wages. This effect is reversed in the stabilization.

\section{When to Stabilize?}

If stabilization were to occur when relative prices are seriously misaligned, quick results could not be expected. Prices that are too low in real terms would still need to rise, prices that are too high could be slow to fall. Therefore, the inflation performance in the early aftermath of stabilization would be obscured by the relative price adjustments.

A possible response to this argument is that inflation should be allowed to reach hyperinflation levels, because then synchronization of prices on the exchange rate achieves the adjustment of relative prices, an adjustment that is so elusive at more moderate levels of inflation. Thus, it may be argued that in a hyperinflation, where all prices are set daily or hourly with reference to the dollar, zero inflation can be achieved immediately and at little cost.

This case for delaying stabilization and waiting for hyperinflation is drastically misleading in several ways. First, relative prices in a hyperinflation may not be those of a zero-inflation economy. ${ }^{61}$ In hyperinflation

61. See Kessel and Alchian (1962). 
situations, the price level in dollars can depart by a substantial margin from world prices. ${ }^{62}$ Second, the move to hyperinflation brings about a loss of governability and an arbitrary redistribution of income and wealth. These may well lead to serious political upheaval as happened in Germany. ${ }^{63}$

Another argument for early stabilization recognizes the hysteresis effects of extreme inflation. During a hyperinflation, tax administration and compliance erode, financial institutions adapt, and pricing shifts to a short horizon. Stabilization may not reverse these changes for some time. Therefore, stabilization must be far more vigorous if it occurs late in the game.

It may be, however, that while sound economic arguments can be made for early stabilization, political considerations outweigh them. A cure to the inflation problem requires political consensus for, and a commitment to, balancing the budget. When inflation is moderate to high, budget balancing is viewed as a negative sum game. Too many participants feel that stabilization is costly to them and too few perceive that the reduction in resource waste will more than cover their costs. ${ }^{64}$ Party politics will dominate, coalitions for disinflation will be blocked, and inflation stabilization will not often succeed. Furthermore, a series of temporary stabilizations, often only the result of controls, lowers credibility and thus raises the difficulty of stabilization in the next round.

According to this view, it is better to let inflation escalate all the way. In a hyperinflation, the disruption of normal economic life and the extravagant cost of carrying on business that are caused by extreme inflation create the political basis for a national unity government or emergency powers, which would be the basis of a forceful and lasting stabilization.

This line of argument is more persuasive. But one must still ask at what stage should the stand be taken-at 30 percent per month, 50 percent per month, or an extreme 1,000 percent per month? One can turn the argument around to say that stabilization will not be accom-

62. This is a reflection either of the flight from money, leading to a decline in the real exchange rate, or of a premium on goods, leading to prices that are extravagantly higher than world prices.

63. See Fergusson (1975) and Guttman and Meehan (1975).

64. Fernandez and Rodrik (1990) argue that the status quo, as wasteful as it is, has its attractions. 
plished without deep reforms and that these cannot be accomplished without broad political consensus. Policymakers should therefore focus on getting the necessary political support, in the recognition that "politically impossible" is the key phrase accompanying the progressive slide into hyperinflation.

\section{Orthodox or Heterodox Stabilization?}

The role of incomes policy-wage-price agreements and freezes-in stabilization programs is the focus of vigorous debate. Such policies were used in Israel and Mexico's successful programs, but they were also part of the failed programs of Argentina, Peru, and Brazil. In the successful Bolivian stabilization, by contrast, incomes policy had no role, nor did it in the stabilizations of the 1920s.

Incomes policy enters the discussion because of the argument that inflation has substantial inertia. This inertia stems from explicit or implicit indexation in the environment of high inflation (but not hyperinflation). Moreover, with staggered price and wage adjustments and an emphasis on restoring real price or wage relations when adjustments occur, inflation has a momentum almost independent of demand.

Suppose now that money growth were stopped, and assume for the sake of argument that it were stopped "credibly." Would the end of monetary expansion signify a rapid reduction in inflation without significant unemployment? Specifically, will economic agents abandon the backward-looking indexation approach to price and wage setting and spontaneously realign nominal prices to be consistent with the new monetary policy and with equilibrium in goods and asset markets under noninflationary conditions? There is no case of a large country with high inflation that stabilized quickly by simply changing the monetary-fiscal regime. In very small, open economies exchange rate stabilization may cause rapid transition. But in large economies with a substantial internal market, the transition is complicated.

The absence of a particular example may only mean that the belief in inertia is so predominant that governments are under its spell. Or it may mean that they have not tried because they feel they cannot make credible commitments and hence fear that the jump to stability may land them short.

Stabilization can be thought of as an operation. The essential need is 
surgery; anesthetics may or may not be used. In this analogy, the change in the monetary-fiscal regime represents the surgery and incomes policy the anesthetic. Below we show various stabilization experiences. In theory, heterodox programs fall into the upper left-hand box; in practice, they risk slipping to the right. Orthodox programs fit squarely into the lower left.

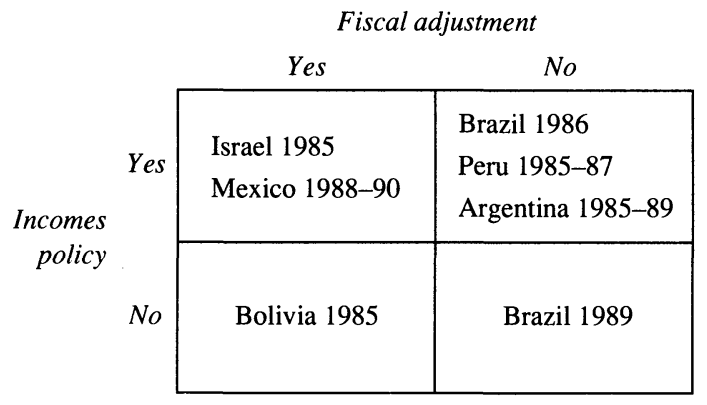

Clearly, Peru, Brazil, and Argentina used only the anesthetic, which provided temporary relief. The operation never took place, and the disease, far from disappearing, became more virulent. Bolivia, on the other hand, underwent the operation-an abrupt shift to a monetary target-but declined the anesthetic. ${ }^{65}$ Mexico and Israel successfully reduced inflation, and did so without a major reduction in real activity. They both used incomes policy on an equal footing with fiscal correction.

\section{Arguments for Heterodoxy}

There are several basic reasons why incomes policy can accompany stabilization. ${ }^{66}$ First, until an economy has converged to virtually daily pricing of goods and labor, some prices, wages, or contracts will always be out of line. An example would be medium-term contracts-a few months long for debt, a year in some cases of rent. Incomes policy provides an effective means of realignment.

Readjustment is particularly important for debt contracts that have maturities of a few months. The sudden drop of inflation in the context

65. There was some incomes policy used in that union leaders were temporarily sent into exile. See Morales (1988).

66. For arguments concerning heterodoxy in stabilization, see Arida and Lara-Resende (1985), Pereira and Nakano (1987), and Dornbusch and Simonsen (1987). Also see Shupp (1976) and Artstein and Sussman (1990). 
of stabilization would, in the absence of an imposed settlement, imply unusually high realized real interest rates that then drive some debtors into bankruptcy.

The second argument for incomes policy involves the coordination problem. In the adjustment to a new monetary regime, economic agents need to reset their prices. This resetting brings into play expectations about what other parties think and how accommodating the government might be if something goes wrong. Economic agents are likely to respond by continuing with price increases, triggering the need for a demonstration of policy determination. The real issue is to stabilize at minimum cost. Incomes policy - when strictly temporary and when used to accompany major monetary and fiscal adjustment-can help solve the coordination problem by establishing true price stability.

The third argument involves the budget. Where high inflation erodes real revenue from tax collection, stabilization yields an immediate gain in real revenue. Stabilization also allows strictly temporary monetization, which provides breathing space in which to deepen the fiscal reform. This breathing space also serves to accomplish other important structural reforms: in financial markets, and in the area of exchange rates, where protection will inevitably be required. The demonstration of actual price stability, after the trauma of extreme inflation, creates highly favorable political conditions that can serve as the critical stepping stone for achieving these elusive reforms. This favorable climate carries a risk as well-with the alarm bells switched off, governments can become complacent.

Before considering the arguments against incomes policy, we note some implications of the simulation model discussed earlier. This model gives strong support to incomes policy as a coordinating device accompanying a fiscal correction. Once an increase in government expenditure has shifted the economy to a new inflationary path, a return to the initial level of expenditure will not return the economy to zero inflation. The budget will remain in deficit due to the inflation-induced reduction in real revenue. Thus, successful stabilization requires fiscal overshooting. The fiscal correction must be sufficient to eradicate the inflationary momentum of the economy. Only after zero inflation has been achieved can fiscal expenditure return to its initial level without inflationary consequences.

The need for fiscal overshooting can be minimizèd by price and wage 
freezes that reduce the cost of stabilization. A temporary price and wage freeze, imposed at the moment of stabilization, increases real tax receipts and thereby reduces the extent of budgetary correction needed for a return to the zero-inflation steady state.

\section{The Counterargument}

Opponents of incomes policy argue that it detracts from the central focus of a stabilization, namely the change of regime. Incomes policies may obscure the extent to which a regime change has occurred. Or, they may carry forward the need for adjustments in relative prices, which would be better resolved immediately so that they do not become sources of renewed inflationary expectations. Or, finally, incomes policy, by suppressing the symptoms, may undermine the very willingness to attack the disease at the roots.

Noting the cycles of open and repressed inflation in Brazil, as shown in figure 7, Miguel Kiguel and Nissan Liviatan conclude strongly against the use of incomes policy. ${ }^{67}$

Until there is sufficient resolve to deal with inflation (and pay the cost of disinflation) there is no way in which the inflationary trend could be reversed in each of these countries. However, much of the excessive instability could have been prevented by avoiding the repeated use of incomes policies. . . . Given the recurrent failures during the cycles period there is no possibility in the present situation of avoiding the confrontation between pessimistic expectations and the effort to set nominal anchors. . . Further use of price controls should be avoided in order to restore credibility in conventional anchors.

With each round of failed stabilization, the case against heterodoxy becomes stronger. In fact, even the temporary results can be questioned. The results may primarily reflect a cycle where a freeze is anticipated, which leads to precautionary increases in list prices. Accordingly, there is an appearance, in the early phase of a freeze, of low inflation that in reality only represents temporarily low transactions prices. Figure 8 strongly bears out this phenomenon for the case of Argentina.

Thus, the counterargument centers squarely on the need to establish a credibility in a new monetary regime that can serve as an anchor. ${ }^{68}$

67. Kiguel and Liviathan (1990a, pp. 32-33).

68. On the issue of credibility see Barro and Gordon (1983), and the reviews by Persson (1988) and Blackburn and Christensen (1989). 
Figure 7. Inflation during Brazil's Stabilization Plans, 1984-90a

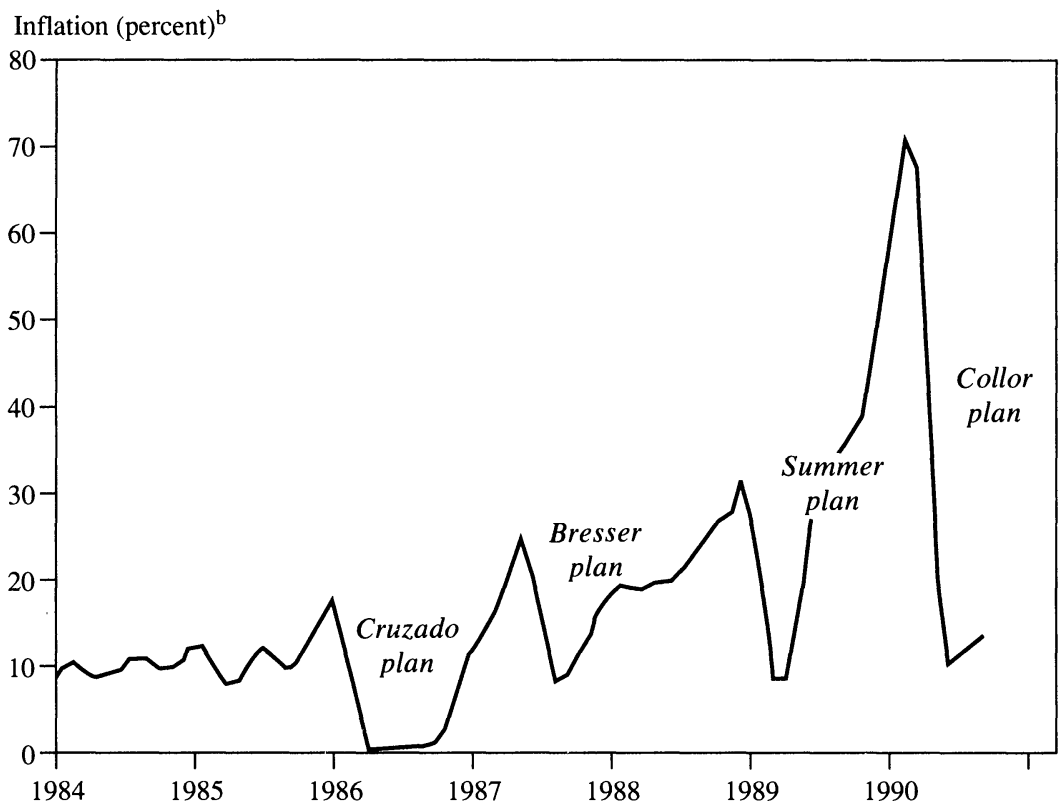

Source: Authors' own adaptation from Cardoso (forthcoming) using data from International Financial Statistics, various issues.

a. The four inflation stabilization plans have been the Cruzado plan (January 1986), the Bresser plan (May 1987), the Summer plan (December 1988), and the Collor plan (April 1990).

b. The inflation measure is a three-month moving average.

\section{Credibility: What Is Enough?}

Some theoretical work on stabilization centers on the notion of credibility and on the need to establish this credibility by a decisive regime change. Without questioning the broad notion of credibility, we qualify how much can be expected from it.

Credibility is overrated as a concept. One government cannot establish permanent conditions: the next government could make a U-turn, the current government may even find it convenient to do so.

In practice, the public lives with the actual facts and does not speculate much about whether a current stabilization will last a year or forever. It is near-term credibility that matters-can the exchange rate be held and will high interest rates persist? In Germany's 1923 stabilization, for example, inflation was stopped by budget control and supertight money, 
Figure 8. Argentina: Response of List Prices to Price Freezes, 1986-90 ${ }^{\mathrm{a}}$

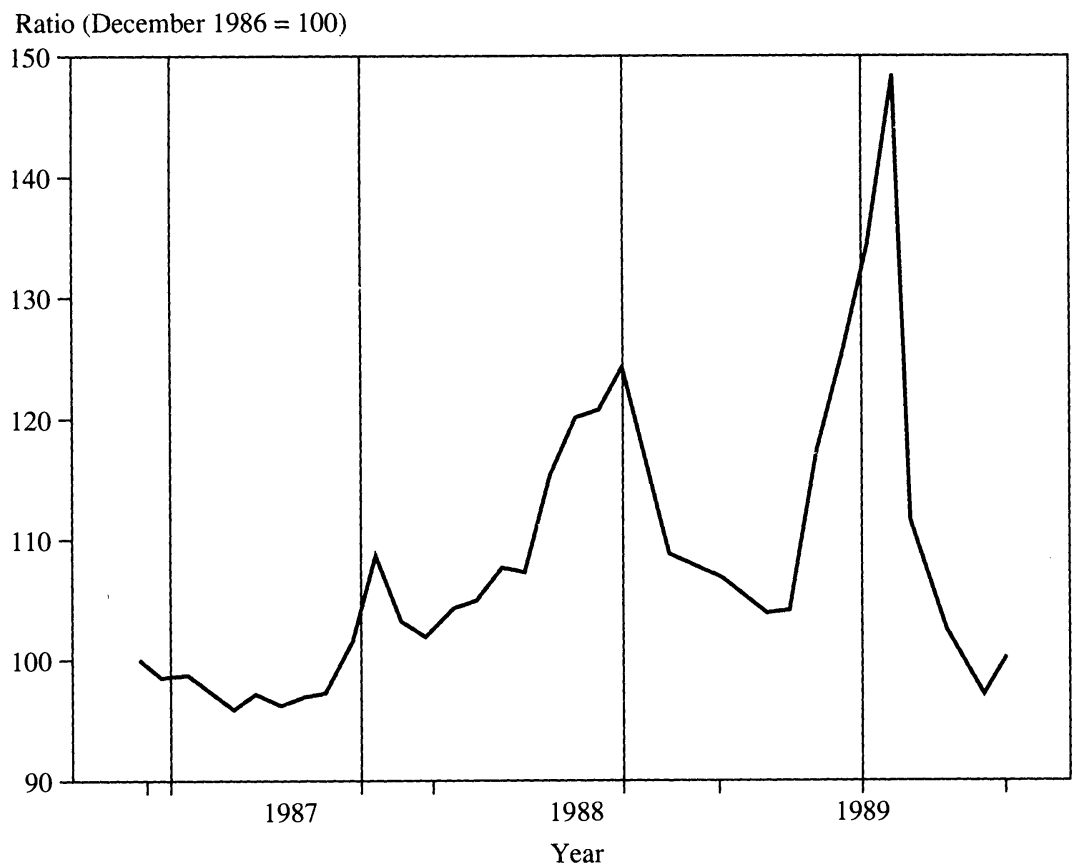

Source: Unpublished data from Fraga and Associates Consulting Firm, Buenos Aires.

a. The ratio of list prices to transaction prices is shown. Vertical lines correspond to price freezes.

even though month after month expectations of stabilization were at best precarious. ${ }^{69}$ Similarly in Israel's stabilization, doubts about medium-term success continued to be voiced months after inflation had already come down.

Institutional change is often emphasized as a key ingredient in establishing credibility; a move to gold or the introduction of an independent central bank are specific examples. ${ }^{70}$ Although the creation of an independent central bank would be a crucial step, ${ }^{71}$ a government that is unwilling to balance the budget is hardly likely to do so. Attention should, therefore, focus more on the budget and less on the central bank

69. See Webb (1989), Eichengreen (1986), Siklos (1990), and Dornbusch (1987).

70. See Republic of Poland (1926).

71. Chile, for example, has just made its central bank independent and New Zealand changed the responsibility of its central bank to the exclusive pursuit of price stability. 
arrangements. If the budget is not balanced, the government will create some kind of money. ${ }^{72}$

Credibility is best established by pervasive fiscal reform: putting in place a tax system that collects revenue from a broad tax base with moderate tax rates, and enforcing the law fiercely. In Argentina, for example, if ten million people rather than three thousand were made to pay taxes, the fiscal problem would not exist. The auditing of one out of every ten high income people in Mexico, for example, has established an infrastructure of lasting fiscal stability.

Thoroughgoing fiscal reform, both with respect to the tax base and tax administration, is important because it protects against shocks. With a broad tax base and an indexed tax system, shocks to the budget can be met by small changes in marginal taxes. Without those safeguards, inflationary finance is the automatic response.

External support has a special role to play in stabilization, especially as it affects credibility. While certain IMF programs, like incomes policy, have lost their glamour after much failure, external measures can still contribute in two critical ways. First, external parties can monitor programs when credit is linked to performance. Austria and Hungary in the 1920s had such an arrangement with the League of Nations. Resident commissars reinforced discipline and watched the budget daily. Tax reform was a precondition for stabilization loans, and the commissar could deny approval of spending projects. ${ }^{73}$ The United States played a monitoring role in the case of Israel's stabilization.

Second, external support can provide the foreign exchange that is essential for exchange rate stabilization. The availability of foreign exchange reserves raises the backing of domestic money, thus improving confidence. Coupled with a balanced budget, foreign exchange backing represents strong support for an anti-inflation program. Foreign support can take different forms including the acceptance of suspension of resource transfers. For both Germany and Bolivia, this was a precondition for stabilization. ${ }^{74}$

72. In Poland in the 1920 s, following the introduction of an independent central bank, there was another inflation based on the Treasury's residual right to mint coins! See Dornbusch and Fischer (1986).

73. See League of Nations (1926a, 1926b).

74. See Sachs (1987) and German Foreign Office (1922). 
Whether external support is decisive or not is open to question. The League of Nations did arrive at a clear-cut conclusion, arguing that "loans and credit from abroad were neither sufficient by themselves to bring about effective stability, nor were they always necessary to that end." ${ }^{75}$ But in the 1920s, and later in Bolivia and Israel, the importance of foreign support is not in question. Although the central action has to be fiscal and monetary reform, foreign financial support helps to mobilize confidence and to encourage repatriation of capital flight. Thus, external support critically eases the adjustment.

\section{Nominal Anchors}

A final question concerns the choice of nominal anchors. Should the central bank define its policy in terms of an exchange rate rule, a monetary target, or some combination $?^{76}$

If inflation were to stop abruptly, without a fall in the price level and without an increase in real balances, the real money supply would continue at its low level. Faced with conditions left by the preceding high inflation, the government can either bring interest rates down by monetary expansion, given the price level, or it can contain nominal money growth and force a reduction in the price level through currency appreciation and the threat of recession.

A monetary expansion could take place by either financing the government or monetizing foreign exchange inflows. The high nominal interest rate reverses previous capital flight, or dollarization. In supporting a given exchange rate, the central bank could simply remonetize the economy with a marginal reserve backing of 100 percent. In this setting, real money would gradually rise and real interest rates fall. A fixed exchange rate is an attractive option in that it establishes an immediate focal point for coordinating price expectations and price setting. Moreover, if confidence is strong and, as a result, capital is substantially mobile, remonetization will occur in good time. As shown in equation 10 , the private sector surplus would become a channel of remonetization.

75. League of Nations (1946, p. 131).

76. See Dornbusch (1982) and Fischer (1988) on the issue of exchange rate and monetary targets. 
The risk of a strategy based on exchange rates comes from the side of inflation. If prices do not stop rising shortly after rates are fixed, progressive overvaluation develops. In turn, overvaluation creates expectations of devaluation. To avoid this problem, exchange rates should be fixed at the outset, but soon after should switch to a crawling peg in order to maintain the real exchange rate. This measure increases inflationary pressure in the economy and therefore shifts more weight to the budget as the central stabilizing force. Overvaluation notwithstanding, to advocate a fixed exchange rate, with the idea that the resulting recession would teach price setters a lesson, is risky. It may fail on political grounds.

An important caveat must be made with respect to the financing of reserve acquisition. Again equation 10 is helpful. One view holds that monetization of reserve flows cannot be problematic because of the marginal 100 percent backing; in case of capital outflows, the central bank can readily buy back the domestic money stock. However, if the central bank in the foreign exchange market monetizes the foreign exchange counterpart of trade surpluses, there may be trouble. Monetizing trade surpluses is just as inflationary as building monuments with central bank credit. The continuing inflation in Argentina can be explained by the fact that the budget surplus is not large enough to sterilize the effect of foreign exchange purchases on the money supply, which arise from the private sector trade surplus.

It is true that when foreign exchange operations correspond to an accommodation of a portfolio shift from foreign to domestic money, intervention and monetization have no inflationary impact. But when the foreign exchange purchases correspond to trade surpluses, that logic no longer applies. For example, when a government with a balanced budget depreciates the exchange rate at a given rate, the public will anticipate inflation and inflation will in fact emerge (or continue). Thus, the public pays an inflation tax, except that in this case it finances the acquisition of reserves rather than the budget.

An alternative strategy centers on monetary control. The exchange rate would be allowed to fluctuate freely. Under this policy, an immediate overvaluation may occur due to high interest rates and momentary confidence. The overvaluation increases the risk of a deep and protracted recession, which would directly undermine the fiscal stabilization through the cyclical effect on revenue and through the risk of political U-turns. 


\section{Damned If You Do, Damned If You Don't?}

In the most recent stabilization efforts of Argentina and Brazil, incomes policy has no part. This time around policymakers insist that fiscal and monetary control, rather than incomes policy, are the keys to controlling inflation. Budgets, on a cash basis, have been balanced and monetary control (after remonetization) is in place. Even so; inflation has not vanished. In fact, with weekly adjustments in prices widely reported, a new inertia has trapped the economies at unacceptably high inflation rates.

The predicament of Brazil and Argentina today is that cash budget surpluses have not been enough to stop inflation. Inertia is so pervasive (and the cut in the real wage already so large) that the state of recession does not readily produce further reductions in the inflation rate. Credibility works to contain the current inflation until further notice, but it does not produce a disinflation without the actual demonstration of deeper recession. That showdown still lies ahead and depends on the resolve of the central bank to control money growth fully.

The Argentine and Brazilian governments now face a choice. One strategy is to add incomes policy to the already changed monetary and fiscal regime. The combination could help bring inflation down to singledigit levels. The alternative is to further tighten fiscal restraint-preferably by deepening reforms rather than by emergency measures-and to harden the restraint on nominal money growth even if that means a strongly overvalued real exchange rate. The resulting decline in activity, if large enough, would ultimately yield lower inflation. This approach would need to be pursued over a few months, possibly longer. In deciding which alternative to use, governments must consider certain factors. First, the introduction of incomes policy is unattractive because it connotes failure and may be counterproductive with respect to expectations. Second, the alternative strategy of further tightening is costly, both economically and politically, and in the end may fail because credibility in the political scenario could break down.

Not even the prospect of reestablishing credibility through a deep and long recession is plausible because democratic governments and their policies are not exogenous and cannot be precommitted. Through the backdoor comes incomes policy, with all its bad reputation, because it does have short-run effects. 
A radical alternative, for countries like Argentina or Peru whose governments are administratively and politically weak, is adoption of the dollar as a national currency. Seigniorage aside, if the budget were balanced, such a move might dramatically lower the costs of transition to a low inflation that lasts. Although the loss of seigniorage must be taken seriously, it can be overcome. ${ }^{77}$ Argentina is already almost fully dollarized. Unless people expect stabilization to be accomplished quickly and effectively, bringing with it a de-dollarization, the seigniorage argument does not stand up. As illustrated in table 14, Bolivia's continuing dollarization serves as an example. The public already holds a large portion of its transactions balances in U.S. dollars; local money serves only as small change. In the banking system, dollarization is advancing because it is the only plausible, safe way of intermediating on shore.

The decisive step would be to prohibit any further domestic currency issue, which would allow the existing stock of domestic currency to serve the transactions needs. The entire banking system should be put on a dollar basis, thus facilitating a resumption of intermediation that can help ease the adjustment process.

It stands to reason that Argentina, with a 20-year history of extreme instability, may have a brighter future without a national money. This may be the lowest cost strategy to overcome stubborn expectations. The same argument applies to Peru, where dollarization is already well along. Indeed, the distance to full dollarization is much shorter than the distance back to a sound national money.

\section{Concluding Remarks}

After briefly summarizing a number of our findings, we comment on a critical direction of research. High inflation is an intrinsically unstable process; the more inflation a country has, the more inevitably it is drawn into rapidly accelerating price increases. Also, high inflation is a process that involves an endogenous money supply in a critical way. The budget deficit increases as a result of high inflation due to the erosion of real tax revenue and the lags in adjusting public sector prices. The frequency of 
Table 14. Money Holding in Bolivia, $1980-90^{\mathrm{a}}$

Percent

\begin{tabular}{ccccc} 
& & & \multicolumn{2}{c}{ Time deposits } \\
\cline { 3 - 5 } Year & Currency & $\begin{array}{c}\text { Sight } \\
\text { deposits }\end{array}$ & $\begin{array}{c}\text { Held in } \\
\text { national } \\
\text { currency }\end{array}$ & $\begin{array}{c}\text { Held in } \\
\text { U.S. } \\
\text { dollars }\end{array}$ \\
\hline 1980 & 41.0 & 20.7 & 26.0 & 12.3 \\
1984 & 72.0 & 10.7 & 17.1 & 2.6 \\
1986 & 35.8 & 8.4 & 20.5 & 31.0 \\
1989 & 22.3 & 9.2 & 5.3 & 57.3 \\
$1990^{\mathrm{b}}$ & 17.4 & 8.7 & 4.5 & 63.4 \\
\hline
\end{tabular}

Source: Banco Central de Bolivia, Boletin Estadistico 265:14 (March 1990)

a. Numbers represent the average percent of $M 2$ held in a specific form.

b. The 1990 numbers are for March only.

price adjustment for goods and labor responds to the rate of inflation and in turn feeds the acceleration of inflation.

Furthermore, the financial system adapts pervasively to high inflation and so erodes the scope for noninflationary seigniorage. When the system fails to adapt, radical dollarization is the consequence. Real exchange rate collapse plays a central role in initiating and propagating high inflation. In addition, there can be no stabilization without monetary control. Monetary control requires budget balancing to an extent sufficient to incluade even the exchange purchase associated with a fixed exchange rate in the presence of trade surpluses. Also, incomes policy can play a critical role in achieving the transition to low inflation, but it cannot be a substitute for fiscal control. Credibility is best built by institutional reform in the public sector. This means tax and expenditure reform. Finally, external support is a critical ingredient for stabilization; it helps mobilize confidence and thus offsets, at least partially, the fragility of a post-hyperinflation economy.

Two main puzzles emerge from our study of extreme inflation. The pricing of goods does speed up in response to high inflation, and can even reach hourly frequency in extremes. Yet, the acceleration is surprisingly slow. The sluggish response is even more apparent in the reluctance to automatically adapt wages to current inflation. The stickiness of payment intervals for labor services is equally puzzling. A richer explanation of these stylized facts is needed. 
Also, the pervasiveness of U-turns in macroeconomic policy begs for a political model. Why do governments make U-turns, inflating one day freely and staging a violent anti-inflation policy the next? A central finding in a review of a large number of stabilizations is the corresponding change in the political scene: the trauma of extreme inflation brings national unity governments or governments that enjoy emergency powers. This was as true for Germany, Austria, and France in the 1920s as it was for Israel in the 1980s. In the end, the dynamics of this political consensus remain as an important issue for further study.

\section{APPENDIX}

\section{The Simulation Model}

OUR MODEL is an extended version of Olivier Blanchard and Nobuhiro Kiyotaki's 1987 model and introduces inflation, elastic money demand, and endogenous money growth. Money is derived from the government budget constraint that includes a Tanzi effect.

The economy is composed of a finite number of consumer-producers who maximize an intertemporal utility function defined over consumption, real monetary balances, and labor effort. We use three agents in our simulation. They maximize:

$$
U_{i}=\int\left[\left(C_{i} / g\right)^{g} M /(P(1-g))^{1-g}-(\theta / \beta) Y^{\beta}\right] e^{-\delta t} d t,
$$

where all variables are functions of time. $C_{i}$ is a constant elasticity of substitution (CES) index of commodities and $P$ is the corresponding price index. Each individual must decide on consumption, real monetary holdings, and production. Each agent faces the following budget constraints, over all $j$ goods:

$$
\sum_{j} P_{j} C_{j i}+M_{i}=P_{i} Y+M_{i, t-1}-P \gamma(\pi),
$$

that is, consumption plus nominal balances equals income plus money holdings in the previous period minus taxes. Taxes, represented by a function $\gamma$, fall with inflation so that $\gamma^{\prime}<0$. This function is arbitrarily imposed in the model.

The government buys fixed amounts of all goods. It finances itself 
both with taxes and money creation. The budget constraint of the government is

$$
P C_{g}=\Delta M+P \gamma(\pi),
$$

where $C_{g}$ denotes government consumption. Solving the maximization problem for the consumer, we find that velocity is a function of inflation. ${ }^{78}$ We also obtain a demand function for each commodity as the sum of the individual demands of each agent. This demand function is a function of the relative price of the firm and of aggregate real monetary balances.

Each individual determines her optimal price by maximizing an indirect utility function, having been given the optimal choices of consumption and money holdings and the economywide demand for her product. We do not impose the restriction that each firm is small and that changes in individual prices do not affect the general price level. If there exist different groups with homogenous "menu costs," they will behave similarly—a fact that is anticipated by firms and has discrete effects on the price level. This makes the maximization problem quite complicated; the general equilibrium price level is solved from the nonlinear solution to the three first-order conditions for each individual firm. The equilibrium price level is a function of the overall quantity of money in the economy.

We assume initially that with zero inflation taxes are enough to finance government spending. Thus, we generate an equilibrium for the economy where inflation is zero and money does not grow. We then introduce fiscal shocks by increasing government spending. The primary deficit is financed by printing money. The increase in money raises the individual demands, thereby increasing the optimal price for each consumerproducer. Eventually some firm (depending on its exogenous cost of changing prices) finds it desirable to change its price.

Adjustments by this first firm may then trigger adjustments by other firms, since goods are substitutes. Eventually the economy settles into a Nash equilibrium for the period, where no firm wants to change its price given the prices of the other two. The higher equilibrium price level affects the budget constraint of the government in two ways: it increases nominal government spending and reduces government revenue. Both effects require an increase in the quantity of money in order to finance

78. This finding corresponds with the one by Dornbusch and Mussa (1975). 
its primary deficit, thereby triggering a new round of adjustments. The final solution (for the period) is reached when no further adjustment takes place. More formally, the following iterative algorithm is solved in every period: ${ }^{79}$

Step one. Given an initial value for $P_{t}$, determine current money $M_{t}$ from equation A3.

Step two. For each producer, determine whether an increase in her price is optimal, keeping the remaining prices at their original values.

Step three. If at least one producer adjusts under step two, change those prices to their new optimal level. Recalculate whether adjustment has become optimal for the remaining producers.

Stepfour. If at least one producer adjusts under step three, recalculate the optimal prices for the producers that had adjusted under step two. Using these new prices, repeat from step three.

Step five. Using the individual prices obtained, calculate the overall price level. If this level differs from the initial guess by more than 0.1 percent, repeat from step one.

79. Gauss computer programs for the model are available upon request. 


\section{Comments and Discussion}

Stanley Fischer: This is an excellent paper, with an eminently believable story line and much exciting detail. The authors document a number of destabilizing mechanisms that gradually appear in high inflation economies, including the Tanzi effect, the indexation of labor and other contracts, the shortening of price and wage adjustment lags, financial innovations, and some aspects of exchange rate behavior.

The basic argument must be that once inflation reaches a certain range, it tends to continue rising unless definite action is taken to stop it. The sensitivity of the inflation rate to small shocks probably results from holding the deficit constant and working with seigniorage as the residual source of financing. Under these conditions, with a seigniorage Laffer curve, small changes in revenue requirements can generate large changes in inflation. Although the authors are rightly confident that exchange rate dynamics play an important role in the inflationary process, the exchange rate is not fully embodied in the theoretical apparatus.

The conclusions on most controversial issues have the ring of truth and sense. For instance, the authors are surely right to emphasize that most rapid inflations are not the result of an error-free optimizing process by the government, but rather reflect government mistakes and weakness-for example, the view, popular in both Brazil and Israel, that each country had learned to live with inflation through extensive indexation. Of course, emphasis on government errors pushes the analysis of hyperinflation back a step to the questions of why governments are weak and why they make mistakes-but pushing the problem toward its fundamentals is progress in its own right.

Second, the conclusions on heterodox policies are right. The paper clearly sets out the two views about heterodox policies: first that they reduce the transitional costs of stabilization; and alternatively, that 
incomes policies should not be used to try to reduce the transitional costs of stabilization because they allow the government to reduce inflation without addressing the fundamental fiscal issue and thus doom the stabilization attempt. This latter view is for obvious reasons now popular in Brazil and Argentina.

Both arguments may be relevant. The heterodox component was key in persuading the Israeli government to stabilize. For a long time, the fear of a massive recession had stood between the government and a stabilization program. The government was finally moved to stabilize by the argument that wage and price controls would enable the economy to move rapidly to the new noninflationary equilibrium without generating much unemployment. Despite the authors' opinion of the strength of the national unity government in Israel, I do not believe that it would have acted in 1985 if it had believed a major recession would follow.

Incidentally, to expand on the Israeli case, the reason behind the importance of heterodoxy-the government's unwillingness to confront labor-also helps account for subsequent slow growth. The Israeli government started out with a tough program that cut real wages. But after the early success of the stabilization, wages were allowed to rise rapidly. Within six months, the average wage was back to its prestabilization level-and the high real wage helps account for slow growth in the next three years.

Third, the paper makes an important point in arguing that a policy of printing money only to monetize the current account surplus will not necessarily prevent inflation. The Humeian adjustment process must work in the long run. But there is no theory to show that a current account surplus generates the correct growth rate of money in a stabilization. There are cases, such as Argentina at present, where that policy has not stopped inflation.

Let me also raise a few points on which I may differ from the emphasis of the authors. First, although I agree that credibility operates much like a deus ex machina in many models, one wonders occasionally, when studying stabilization attempts, what distinguishes the successful from the unsuccessful. When Rudi Dornbusch and I studied the stabilization attempts of the 1920s, we found it difficult to tell ex ante which stabilizations would work and which wouldn't-and at least one of the co-authors had a sense that credibility was involved. Certainly models with multiple equilibria permit for credibility. 
No one can doubt that some policymakers have credibility and others don't: the Bundesbank has it, and the Banco Central de Argentina does not. The authors must be arguing that credibility does not change fast, that policymakers have to earn credibility through a long record of consistent behavior, and that stabilizations are therefore unlikely to be assisted by a sudden onrush of credibility.

Second, those who argue that it might be wise to wait for hyperinflation before stabilizing are-or should be-making a political and not an economic argument. The point is not that relative prices are more likely to be right when the inflation rate is higher but that politicians are unlikely to move until the public is fully persuaded that the costs of inflation outweigh the costs of stabilizing. That may be wise economically since it enables the policymakers to persist longer with a tougher policy when the costs of stabilization begin to appear.

A third point of contention concerns dollarization. There may be countries, such as Peru and Argentina, where that is the only remaining possibility. But there is bound to be tremendous political opposition to dollarization, on the grounds that using a foreign money derogates from the country's sovereignty. That was the argument that forced the resignation of the finance minister in Israel who proposed dollarization to the Knesset in 1983. It has also to be recognized that dollarization is a tough way of stabilizing. A dollarizing government denies itself the advantage of printing money during the remonetization that accompanies the early stage of a stabilization program. Fiscal policy has to be correspondingly tighter than it would otherwise have been.

Let me turn finally to some puzzles that remain even after reading this paper-

Under what circumstances do countries degenerate into hyperinflation? The paper suggests that hyperinflations occur in countries with socially and politically divided populations, and weak governments. That is true for Peru, Argentina, Brazil, and Yugoslavia. It was less so in Israel. Further work should clarify the necessary and sufficient conditions. The weak French governments of the 1950s, and the continuing weakness of Italian governments, have not produced hyperinflations. The strength of the central bank and the civil service must play a role; other factors are no doubt important too.

Is there any role for the notion that mistaken policy rules lead governments to hyperinflate? Policies such as holding the real interest 
rate constant, or holding the nominal exchange rate constant, have done their share in some hyperinflations.

Is there any point at which extreme inflation becomes inevitable? Is Colombia, with its stable 20 percent annual inflation, destined to hyperinflate? I don't know.

Why does the inflationary process appear to be asymmetric? Why, when inflation reaches the high double digits, are all jumps upward-or is that just a selection bias, in which we study the cases in which jumps have been upward? Why don't the mechanisms that speed up the inflationary response to adverse shocks speed up the deflationary response to beneficial shocks?

Why don't gradualist stabilizations work?

Is it ever the case that all it takes to stabilize is to fix the exchange rate, or some other nominal variable, without changing the fiscal deficit? The Tanzi effect makes this theoretically possible; it may have happened in Yugoslavia at the beginning of this year-although the Yugoslav stabilization is now in severe trouble-and in Italy in 1947.

Do governments ever hyperinflate deliberately? This claim has been made for both the German and Russian hyperinflations of the early 1920s.

Finally, is the central role of seigniorage in modern models of inflation convincing? Seigniorage rarely amounts to more than 3-4 percent of GNP, and is frequently a much smaller share. Our models say that is all that is driving the inflation, that inflation would disappear if the deficit were cut by that amount. The logic is impeccable. But that is a very small tail to wag such a big dog.

Robert J. Barro: Rudiger Dornbusch, Federico Sturzenegger, and Holger Wolf's paper stresses that inflation interacts in several ways with real phenomena, such as the government's budget, the operation of financial markets, and wage determination. Thus, an immediate question is how significant the link is between real performance and the amount and variability of inflation. To explore this issue, I have examined the relationship between inflation and the growth rate of real per capita GDP from $1970-85$ in a cross section of 117 countries. Figure 1 reveals a negative but weak relation between the GDP growth rate and the average inflation rate from $1970-85$; the correlation is -0.19 . Figure 2 reveals a weak negative relation between the growth rate and the coefficient of 
variation in inflation. In this case, the correlation for 108 countries is -0.20 . (The highest coefficient of variation is 2.50 for Oman. Because Oman maintained a fixed exchange rate with the U.S. dollar in most years, the Omani price level is basically the U.S. dollar price of oil.)

Figure 3 shows the relation between the GDP growth rate and the change in the inflation rate, measured by the average rate for 1970-85 less the average rate for 1960-70. The correlation for 114 countries is -0.25 , but is dominated by some extreme observations: the sharp reduction in the inflation rate for Indonesia and the sharp increases for Argentina, Bolivia, Israel, Chile, Uganda, and Peru. Figure 4 shows the pattern when the extreme values are deleted. In this case, the correlation for the remaining 107 countries is a weaker -0.16 .

I added the measures of inflation intensity to a growth-rate regression of the type that I estimated in a previous study for 98 countries. ${ }^{1}$ The dependent variable is the growth rate of real per capita GDP from 1970 to 1985 . The independent variables are the level of real per capita GDP in 1960, school enrollment rates in 1960 (a measure of human capital), the share of GDP from 1970-85 taken by government consumption purchases, and other variables that measure political stability and price distortions. In this setting, the inflation variable that matters most is the change in the inflation rate from 1960-70 to 1970-85. The estimated coefficient, -0.033 , with a standard error of 0.012 and $t$-statistic of 2.7 , indicates that an increase of 10 percentage points in the inflation rate is associated with a 0.3 percentage point reduction in the per capita growth rate. When this inflation variable is included, the two other measures of the intensity of inflation-the average inflation rate for 1970-85 and the coefficient of variation of inflation over 1970-85-are insignificant, whereas the change in the inflation rate still has a $t$-statistic of 1.7.

My inference is that real economic performance is significantly and inversely related to an intensification of inflation, although the differences in the behavior of inflation account for only a small fraction of the cross-country variations in growth rates. Moreover, much of the negative relation likely reflects the symptomatic nature of inflation; countries that do badly for other reasons also tend to experience a worsening of inflation.

If inflation is viewed as a distortion of private choices, then the

1. Barro (forthcoming). 
Figure 1. Growth Rate of Gross Domestic Product, the Inflation Rate,

117 Selected Countries, $1970-85^{\mathrm{a}}$

Growth rate of per capita GDP (in percent) ${ }^{\mathrm{a}}$

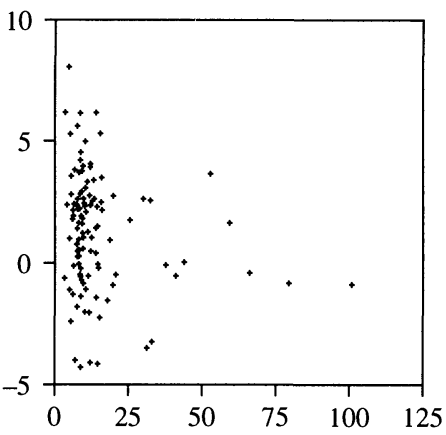

Average inflation (in percent) ${ }^{b}$

Sources: World Bank data base and Summers and Heston (1988).

a. The data on real per capita GDP are the purchasing power parity (PPP)-adjusted values from Summers and Heston (1988). Inflation rates are calculated from GDP deflators from the World Bank's data base. Missing values were filled in from Summers and Heston, using their PPP values and the U.S. price level.

Figure 3. Growth Rate of Gross Domestic Product and the Change in Inflation 114 Selected Countries, 1970-85

Growth rate of per capita GDP (in percent) ${ }^{\mathrm{a}}$

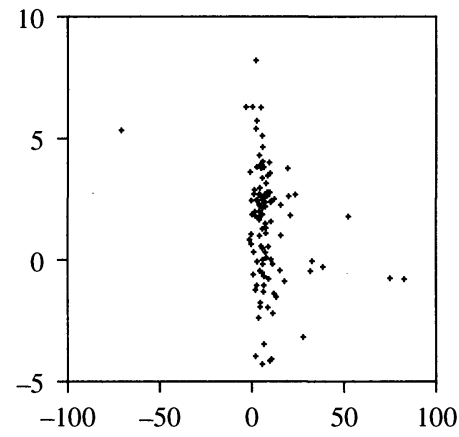

Change in inflation (in percent) ${ }^{\mathrm{b}}$

Sources: World Bank data base and Summers and Heston (1988).

a. For explanation of GDP data, see note a, figure 1 .

b. The change in inflation is calculated by subtracting the average inflation rate between 1960 and 1970 from the average inflation rate between 1970 and 1985 .
Figure 2. Growth Rate of Gross Domestic Product and the Variability of Inflation, 108 Selected Countries, 1970-85

Growth rate of per capita GDP (in percent) ${ }^{\mathrm{a}}$

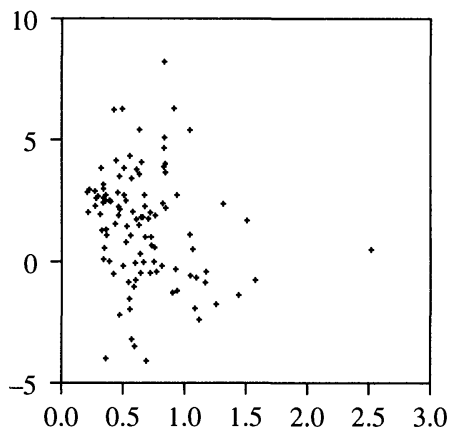

Coefficient of variation in inflation ${ }^{\mathrm{c}}$

Sources: World Bank data base and Summers and Heston (1988)

a. For explanation of GDP data, see note a, figure 1 .

b. The coefficients of variation in inflation were calculated from the annual inflation rates in each country from $1970-85$.

Figure 4. Growth Rate of Gross Domestic Product and the Change in Inflation, 107 Selected Countries, 1970-85

Growth rate of per capita GDP (in percent)

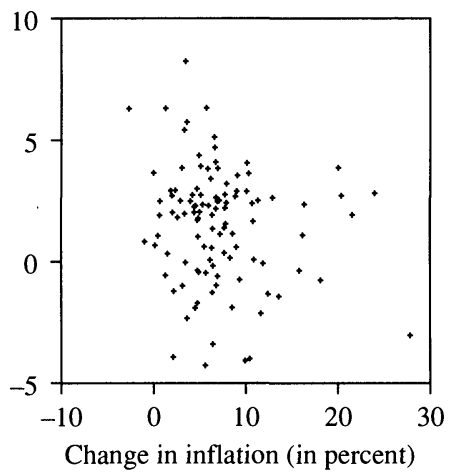

Sources: World Bank data base and Summers and Heston (1988).

a. This figure is the same as figure 3 except that seven extreme observations have been omitted. 
relatively minor role of inflation in real performance is not surprising. Many policies that governments engineer-such as quotas and prohibitive tariffs, high marginal tax rates, licensing requirements and other business regulations, and expropriations of property-represent more substantial distortions. (Only minor parts of these effects are held constant in the above regressions.) It is also true that some of the worst performers, in terms of economic growth, do not have especially bad inflation. For example, for 39 sub-Saharan African countries, the average growth rate of real per capita GDP between 1970 and 1985 was 0.1 percent, compared to 2.0 percent for 75 other countries. The mean inflation rate for the African countries over the same period was 12.3 percent (the median was 9.8 percent), and the mean increase in inflation from 1960 to 1970 was 7.8 percent (the median was 6.5 percent). In contrast, for 75 other countries, the mean inflation rate was 15.8 percent (median, 9.6 percent) and the mean increase in inflation was 9.5 percent (median, 6.6 percent).

A common confusion in the discussion of inflation is the meaning of the term "budget deficit." A government's real sources of revenue include conventional real taxes (the amount of which may be influenced, as the authors stress, by actual and anticipated inflation), the change in the real value of the government's interest-bearing debt, and the revenue from printing high-powered money. ${ }^{2}$ The revenue from money creation can, in turn, be divided into the part associated with expected inflation and the part associated with inflation surprises. The first amounts to an excise tax on the holding of money and the second to a capital levy on money. A capital-levy term could also be separated out from the conventional real taxes.

For a given path of real spending and in the absence of default on the debt (which includes reductions in the real value of nominal debt through unexpected inflation), an increase in the real, interest-bearing debt implies a corresponding increase in the real present value of conventional taxes plus the inflation tax. (The exact correspondence applies if government and private interest rates are the same and if Ponzi games with the

2. The real sources of revenue balance the real uses of revenue if the government's interest payments are calculated with the real interest rate rather than the nominal rate. I assume for convenience that the government does not hold assets, such as buildings, land, gold, and financial claims. Otherwise, the real value of these items would ideally be netted out from the real public debt. 
debt are infeasible.) Thus, it is natural to define the real deficit as the change in the real debt or, equivalently, to include an inflation adjustment in the computation of the budget deficit. The real deficit defined this way has intertemporal implications; namely, a larger real deficit means that the government's tax collections, including the inflation tax, shift from the present to the future. ${ }^{3}$

The authors' discussion conflicts with this view when it refers to financing a "deficit" by printing money. At a later point in their analysis, however, they argue, "Inflation taxes are just as much current taxes as are income taxes; stabilization [of inflation] does not involve shifting taxes over time, as is the case with debt finance. As a result . . real demand should not change. This is not a consequence of Ricardian equivalence, but rather an implication of the shift from an inflation tax to regular taxation.' 'I was surprised, though, by the way this impeccable reasoning was applied to the Israeli experience of the mid-1980s. Higher inflation in Israel did lead to reductions in real tax collections and apparently also to increases in real government spending. ${ }^{4}$ However, my understanding is that variations in the real revenue from printing money were unimportant. That is, variations in the measured public saving rate in Israel mainly represented changes in the rate of flow of real public debt (in the form of indexed obligations). Thus, the Israeli experience represents the type of intertemporal rearrangement of the timing of taxes that comes up in discussions of Ricardian equivalence. The authors could argue with my interpretation of the results of that experiment but not, I think, about the existence of the experiment.

Much of the paper's analysis deals with the stability of inflation in a context of budget-driven endogenous money and the link between inflation and the quantity of real tax receipts. Disturbances to government expenditures or to the real economy change the incentives for inflationary finance and thereby affect the dynamics of inflation. The argument states that, because of endogenous money, even small shocks can drive the economy toward hyperinflation. This result seems to prove too much;

3. This result is consistent with the arguments about inflationary finance in Sargent and Wallace (1981).

4. My understanding of this effect, derived from a discussion with Michael Bruno, is that government departments were allocated a budget in nominal terms to cover spending over some future period. The amount of the allotment took account of the anticipated inflation over the period, an adjustment that would be reasonable if the revenues were held in Israeli currency until spent. Since the funds were actually held in indexed form, the real amount spent increased with the inflation rate. 
after all, hyperinflation is an unusual event. From 1970 to 1985 only 14 of 118 countries had annual inflation rates that averaged more than 20 percent and only 7 exceeded 40 percent average annual inflation. From 1960 to 1970 the corresponding numbers were, respectively, 5 and 1 out of 115 countries.

One element of the dynamics relates to the Bruno-Fischer type of story of unstable inflation. ${ }^{5}$ In the steady state, there are two inflation rates that correspond to a given real revenue from money creation, one on either side of the peak in the Laffer curve. (This setup assumes that the required steady-state revenue is less than the maximum possible.) Under some specifications of inflationary expectations and price flexibility, the lower inflation rate is found to be unstable and the higher rate is found to be stable. ${ }^{6}$ Thus, if the economy begins at the low rate, a shock to government spending could initiate a dynamic path that converges to the high inflation rate.

Consider the example of a beer tax. A given (feasible) amount of real revenue can be obtained with a low tax rate or a high tax rate. Normally, we would regard the high tax rate on the wrong side of the Laffer curve as irrelevant. The implicit assumptions are that the government likes revenue, the distortion is increasing in the tax rate on beer, and the government dislikes distortion for its own sake. (I neglect here negative externalities associated with the consumption of beer.) The high tax rate is irrelevant in this setting because the optimizing government would select the low tax rate.

The question is why the results are different with the inflation tax. The main difference has, I think, little to do with the rationality or irrationality of inflationary expectations, but does depend on the government's ability to generate revenue by causing surprise inflation; that is,

5. Bruno and Fischer (1990).

6. The instability under rational expectations, familiar from the Cagan (1956) model, derives from a restriction on the flexibility of the initial price level; see Sargent and Wallace (1973b). Suppose that the demand for a durable good, $Y_{t}^{d}$, depends negatively on the current price, $P_{t}$, and positively on the (expected and actual) future price, $P_{t+1}$. (For money, the price corresponds to the inverse of the general price level.) The analog to the Cagan demand function is $Y_{t}^{d}=\left(1 / P_{t}\right) \cdot \exp \left[\alpha \log \left(P_{t+1} / P_{t}\right)\right]$. Assume an exogenous path of supply, such as $Y_{t}^{s}=Y$, and market clearing, $Y_{t}^{d}=Y_{t}^{s}$, in all periods. The Cagan exercise is to consider the path of $P_{t}$ for a given arbitrary $P_{0}$. The instability of $P_{t}$ under the Cagan demand function can be shown readily, but the result depends on the assumed rigidity of $P_{0}$. The key aspect of the Cagan demand function in generating this result is that the sensitivity of $Y_{t}^{d}$ to $\log \left(P_{t}\right)$ is greater in magnitude than that to $\log \left(P_{t+1}\right)$. Therefore, an "error" in $\log \left(P_{0}\right)$ is magnified for $\log \left(P_{1}\right)$, further magnified for $\log \left(P_{2}\right)$, and so on. 
by imposing a capital levy on holders of nominally denominated government liabilities. Furthermore, the government is assumed to be unable to commit itself at the outset to resisting these capital levies ex post. ${ }^{7}$ If commitments cannot be supported by formal rules or reputation, the low inflation rate is time-inconsistent and is not an equilibrium. ${ }^{8}$ The high inflation rate is, however, also not an equilibrium in this case. Moreover, the type of dynamics analyzed by Michael Bruno and Stanley Fischer does not arise. ${ }^{9}$ In contrast, if commitments are feasible, then only the low inflation rate is an equilibrium, as in the case of a beer tax. Thus, in either case, these arguments about government revenue from inflation do not have clear implications for the stability and dynamics of inflation.

The discussion does suggest that commitment and credibility are important for the stability of inflation and for reforms aimed at ending inflation. Although these concepts are difficult to measure and hard to translate into policy advice, one implication is that it is unwise to begin a stabilization program by defaulting on past debt obligations; that is, by breaking a past commitment. (Alexander Hamilton would surely frown on this sort of default.)

Other parts of the dynamic story in this paper involve lags in pricewage adjustment and alterations in the frequency of wage payments. I could not see how discrete intervals between adjustments of prices or wages would generate a systematic lag of wages or of the prices of some items behind the general price level. Aside from the fixity of the average relative price at unity, optimal behavior with fixed costs of adjustment entails sufficient overshooting at the outset so that the average gap between the actual and target wage or price is zero. The authors may be saying that empirically a higher inflation rate leads for a while to a lower real wage rate. But this observation is hard to interpret because an increase in the inflation rate is, as suggested before, likely to be symptomatic of an adverse real disturbance that affects the equilibrium real wage rate.

In the discussion of the frequency of payment, I was unsure about the nature of the equilibrium envisioned for the labor market. Suppose that workers get paid the real amount $(w / P) \cdot T$ at interval $T$. I assume that

7. These issue may also arise for a beer tax if consumers get addicted to beer over time and if the government cannot commit itself to abstain from high tax rates in the future. Perhaps this time-consistency argument explains the high (equilibrium) tax rates on addictive goods, such as cigarettes, alcohol, and gambling.

8. See Calvo (1978) and Barro (1983).

9. Bruno and Fischer (1990). 
workers like a higher real wage, $w / P$, and in the relevant range a lower $T$. Competitive firms then face an upward-sloping trade-off between $w / P$ and $T$ and can choose an optimal package based on their own discount rate and the costs of making payments. The argument also goes through if firms have monopsony power in the labor market. Labor supply depends on the $(w / P, T)$ package as evaluated by the workers; firms with monopsony power that face this labor supply function again internalize the workers' trade-off between $w / P$ and $T$.

Dornbusch, Sturzenegger, and Wolf suggest that firms like to keep $T$ high in an inflation because they not only make payments less often but also reduce the value of $w / P$ because of the lag of nominal wages behind inflation. I do not know what kind of equilibrium this represents, but it surely does not derive from monopsony power of firms in the labor market. Perhaps it arises because the government regulates apparent wage rates and the maintenance of a high value of $T$ reduces the overall wage package toward the equilibrium value that would obtain in the absence of government intervention. This result parallels private responses to price controls in the form of reduced product quality and increased delivery lags.

Overall, the paper has many interesting theoretical and empirical insights about inflation. What is lacking, however, is the combination of the ideas into a clear bottom line. This shortcoming is, however, not surprising considering that the central challenge the paper sets for itself is an empirical explanation for the variation in inflation over time and across countries. This task, which goes well beyond the possible fact that "inflation is always and everywhere a monetary phenomenon," has not yet been satisfactorily undertaken.

\section{General Discussion}

Jeffrey Sachs emphasized that one had to know the economic history of and political climate in a country in order to evaluate the particular policy choices considered by the authors-such as whether to use incomes policy or whether to have fixed or flexible exchange rates. In countries such as Poland, where reducing government control and liberalizing the economy are central policy objectives, extensive price controls would conflict with these larger goals. In Argentina, because the new Menem government had been expected to institute wage-price controls, businessmen raised prices 200 percent on the weekend before 
his inauguration, causing inflation problems that might never have occurred otherwise. By contrast, at the onsets of the Austral plan in Argentina and the stabilization program in Israel, wage-price controls were unexpected and probably helped stabilize with little distortionary effect.

Sachs reasoned that incomes policies were most likely to be useful in countries with extensive indexing and centralized wage-setting institutions, particularly in cases where a national union or a union movement allied with the government was involved. In socialist countries, wage controls were needed because there are no real owners of the firms. But in other situations, these conditions were not present. Not only would incomes policy be unlikely to help, but relying on it might divert the government from taking needed policy steps such as fiscal and monetary tightening and market reform.

The model's emphasis on the interaction of the deficit and inflation led Olivier Blanchard to question whether the nature of the initial shock might deserve more study. If, for example, the inflation was started by a conflict over income distribution, then stabilization would be especially difficult and might require a contraction to resolve the diverse claims on national income. Absent a contraction, such a shock might persist. Other types of shocks might be transitory, permitting a quicker and less costly end to the inflation that they cause.

In light of anecdotal evidence and theory predicting that people would go to great lengths to reduce their holding of money during hyperinflations, David Romer expected that real money stocks would fall by larger orders of magnitude than shown in the paper's figures. Rudiger Dornbusch explained that the flight from money became intense once inflation reached, say, 100 percent a year, and well before it reached the hyperinflation stage. Thus the economizing on money holding had already taken place before the start of some figures in the paper.

Sachs agreed that dollarization could, in principle, be an effective way to stabilize inflation. But he noted that dollarization also carried potentially high costs: not only a loss of seigniorage but also a loss of control over the banking system. He observed that Panama could not remonetize its banking system after the United States froze deposits of Panamanian banks. The Panamanian experience also demonstrated how vulnerable a country could become to U.S. interference once that country has dollarized. 


\section{References}

Aftalion, Albert. 1948. Monnaie, Prix et Change. Paris: R. Sirey.

Ahumada, Hildegart. 1989. "Real Money Balances and Inflation: Tests for Asymmetric Effects Using Co-Integration Techniques, Argentina: 19711988." Working paper presented at the IX Latin American Meeting of the Econometric Society. (Spanish).

Alesina, Alberto, and Allan Drazen. 1990. "Why are Stabilizations Delayed?" Harvard University.

Arida, Persio, and Andre Lara-Resende. 1985. "Inertial Inflation and Monetary Reform: Brazil.' In Inflation and Indexation: Argentina, Brazil, and Israel, edited by John Williamson. Washington: Institute for International Economics.

Artstein, Yael, and Zvi Sussman. 1990. “Wage Policy During Disinflation: The Israeli Stabilization." Bank of Israel, Economic Review 64: 1-36.

Bailey, Martin J. 1956. "The Welfare Cost of Inflationary Finance.' Journal of Political Economy 64: 93-110.

Barro, Robert J. 1970. "Inflation, the Payments Period, and the Demand for Money." Journal of Political Economy 78: 1228-63.

- 1972a. "Inflationary Finance and the Welfare Cost of Inflation." Journal of Political Economy 80: 978-1001.

- 1972b. "A Theory of Monopolistic Price Adjustment." The Review of Economic Studies 39: 17-26.

- 1983. "Inflationary Finance under Discretion and Rules." Canadian Journal of Economics 16: 1-16.

-1 1990. "The Ricardian Approach to Budget Deficits." Journal of Economic Perspectives 3: 37-54.

- Forthcoming. "Economic Growth in a Cross Section of Countries." Quarterly Journal of Economics 106.

Barro, Robert J., and David B. Gordon. 1983. "A Positive Theory of Monetary Policy in a Natural Rate Model." Journal of Political Economy 91: 589610.

Benabou, Ronald. 1988. "Search, Price Setting and Inflation." Review of Economic Studies 55: 353-76.

Black, Fischer. 1974. "Uniqueness of the Price Level in Monetary Growth Models with Rational Expectations." Journal of Economic Theory 7: 5365.

Blackburn, Keith, and Michael Christensen. 1989. "Monetary Policy and Policy Credibility: Theories and Evidence.' Journal of Economic Literature 27: $1-45$. 
Blanchard, Olivier J., and Nobuhiro Kiyotaki. 1987. "Monopolistic Competition and the Effects of Aggregate Demand." American Economic Review 77: 647-66.

Blanchard, Olivier J., and Danny Quah. 1989. "The Dynamic Effects of Aggregate Demand and Supply Disturbances." American Economic Review 79: 655-73.

Bresciani-Turroni, Costantino. 1937. The Economics of Inflation; A Study of Currency Depreciation in Post-War Germany, translated by Millicent E. Sayers. London: G. Allen and Unwin, Ltd.

Bruno, Michael. 1989. "Israel's Crisis and Economic Reform: A Historical Perspective." Working Paper 3075. Cambridge, Mass.: National Bureau of Economic Research (August).

- 1990. "High Inflation and Nominal Anchors." Bank of Israel.

Bruno, Michael, and Stanley Fischer. 1986. "The Inflationary Process: Shocks and Accommodation." In The Israeli Economy: Maturing Through Crises, edited by Yoram Ben-Porath. Cambridge, Mass.: Harvard University Press.

- 1990. "Seigniorage, Operating Rules, and the High Inflation Trap." Quarterly Journal of Economics 105: 353-74.

Bruno, Michael, and Leora (Rubin) Meridor. 1990. “The Costly Transition from Stabilization to Sustainable Growth: Israel's Case.' Bank of Israel.

Bruno, Michael, and Sylvia Piterman. 1988. Israel's Stabilization: A TwoYear Review." In Inflation Stabilization: The Experience of Israel, Argentina, Brazil, Bolivia, and Mexico, edited by Michael Bruno and others. Cambridge, Mass.: MIT Press.

Cagan, Phillip. 1956. "The Monetary Dynamics of Hyperinflation." In Studies in the Quantity Theory of Money, edited by Milton Friedman. Chicago: University of Chicago Press.

1987. "Hyperinflation.' In Palgrave's New Dictionary of Economics. London: Macmillan.

Calvo, Guillermo A. 1978. "On the Time Consistency of Optimal Policy in a Monetary Economy." Econometrica 46: 1411-28.

- 1983. "Staggered Contracts and Exchange Rate Policy." In Exchange Rates and International Macroeconomics, edited by Jacob A. Frenkel. Chicago: University of Chicago Press.

- 1985. "Currency Substitution and the Real Exchange Rate: The Utility Maximization Approach." Journal of International Money and Finance 4: $175-88$.

Canavese, Alfredo J., and Guido Di Tella. 1988. "Inflation Stabilization or Hyperinflation Avoidance: The Case of the Austral Plan." In Inflation Stabilization: The Experience of Israel, Argentina, Brazil, Bolivia, and Mexico, edited by Michael Bruno and others. Cambridge, Mass.: MIT Press.

Cardoso, Eliana. Forthcoming. "From Inertia to Megainflation: Brazil in the 1980s." In Lessons of Economic Stabilization and its Aftermath, edited by Michael Bruno. Cambridge, Mass.: MIT Press (forthcoming). 
Cavallo, Domino F. 1982. "Comments on Indexation and Stability from an Observer of Argentine Economy." In Inflation, Debt, and Indexation, edited by Rudiger Dornbusch and Henrique Simonsen. Cambridge, Mass.: MIT Press.

Cecchetti, Stephen G. 1986. "The Frequency of Price Adjustment." Journal of Econometrics 83: 255-74.

Cukierman, Alex, Sebastian Edwards, and Guido Tabellini. 1989. "Seigniorage and Political Instability."' Working Paper 3199. Cambridge, Mass.: National Bureau for Economic Research (December).

Diamond, Peter. 1990. "Search, Sticky Prices and Inflation." Massachusetts Institute of Technology.

Dornbusch, Rudiger. 1982. "Stabilization Policy in Developing Countries: What Lessons Have We Learnt?' World Development 9: 701-08.

- 1987. "Lessons from the German Inflation Experience of the 1920s." In Macroeconomics and Finance: Essays in Honor of Franco Modigliani, edited by Rudiger Dornbusch, Stanley Fischer, and John Bossons. Cambridge, Mass.: MIT Press.

Dornbusch, Rudiger, and Stanley Fischer. 1986. "Stopping Hyperinflations Past and Present." Weltwirtschaftliches Archiv 122: 1-46.

Dornbusch, Rudiger, and Michael Mussa. 1975. "Consumption, Real Balances and the Hoarding Function." International Economic Review 16: 415-21.

Dornbusch, Rudiger, and Juan Carlos de Pablo. 1989. "Debt and Macroeconomic Instability in Argentina." In Developing Country Debt and the World Economy, edited by Jeffrey D. Sachs. Chicago: University of Chicago Press.

Dornbusch, Rudiger, and Mario Henrique Simonsen. 1987. Inflation Stabilization with Incomes Policy Support: A Review of the Experience in Argentina, Brazil, and Israel. New York: Group of Thirty.

Dornbusch, Rudiger, and Holger Wolf. 1990. "Monetary Overhang and Reforms in the 1940s." Working Paper 3456. Cambridge, Mass.: National Bureau of Economic Research (October).

Drazen, Allan, and Elhanan Helpman. 1988. "Stabilization with Exchange Rate Management." Quarterly Journal of Economics 102: 835-55.

Dutton, Dean S. 1971. "A Model of Self-Generating Inflation: The Argentina Case." Journal of Money, Credit and Banking 3: 245-62.

Eder, George Jackson. 1968. Inflation and Development in Latin America: A Case History of Inflation and Stabilization in Bolivia. Ann Arbor, Mich.: The University of Michigan Press.

Eichengreen, Barry. 1986. "Book Review: Rational Expectations and Inflation." Journal of Economic Literature 24: 1812-15.

Ellis, Howard S. 1934. German Monetary Theory: 1905-1933. Cambridge, Mass.: Harvard University Press.

Evans, J. L., and G. K. Yarrow. 1981. "Some Implications of Alternative Expectations Hypotheses in the Monetary Analysis of Hyperinflations.", Oxford Economic Papers 33: 61-80. 
Fergusson, Adam. 1975. When Money Dies: The Nightmare of the Weimar Collapse. London: Kimber.

Fernandez, Raquel, and Dani Rodrik. 1990. "Why is Trade Reform So Unpopular? On Status Quo Bias in Policy Reforms."' Working Paper 3269. Cambridge, Mass.: National Bureau of Economic Research (February).

Fischer, Stanley. 1981. "Relative Shocks, Relative Price Variability, and Inflation." BPEA, 2:1981: 381-431.

- 1982. "Seigniorage and the Case for a National Money." Journal of Political Economy 90: 295-313.

- 1988. "Real Balances, the Exchange Rate, and Indexation: Real Variables in Disinflation." Quarterly Journal of Economics 103: 27-49.

Flood, Robert P., and Peter M. Garber. 1980. "Market Fundamentals Versus Price-Level Bubbles: The First Tests." Journal of Political Economy 88: 745-70.

Fraga, Arminio. 1986. "German Reparations and Brazilian Debt: A Comparative Study." Essays in International Finance 163. Princeton, N.J.: International Finance Section, Princeton University (July).

Friedman, Milton. (ed.) 1956. Studies in the Quantity of Money. Chicago: University of Chicago Press.

- 1971. "Government Revenue from Inflation." Journal of Political Economy 79: 846-56.

Friedman, Milton, and Anna J. Schwartz (eds.). 1982. Monetary Trends in the United States and in the United Kingdom: Their Relation to Income, Prices, and Interest Rates, 1967-1975. Chicago: University of Chicago Press.

Graham, Frank D. 1930. Exchange, Prices, and Production in Hyper-Inflation: Germany 1920-1923. Princeton, N.J.: Princeton University Press.

German Foreign Office. 1922. Gutachten der Internationalen Finanzsachverstandigen uber die Stabilizierung. Berlin.

Guttmann, William, and Patricia Meehan. 1975. The Great Inflation. London: Gordon and Cremonesi Ltd.

Harberger, Arnold C. 1978. "A Primer on Inflation." Journal of Money, Credit and Banking 10: 505-21.

- 1988. "World Inflation Revisited." In Economic Effects of the Government Budget, edited by Elhanan Helpman, Assaf Razin, and Efraim Sadka. Cambridge, Mass.: MIT Press.

Heyman, Daniel. 1990. "From Sharp Disinflation to Hyper and Back: The Argentine Experience, 1985-1989." Buenos Aires: CEPAL.

Kessel, R. A., and A. A. Alchian. 1960. "The Meaning and Validity of the Inflation-Induced Lag of Wages Behind Prices." American Economic Review 50: 43-66.

- 1962. "Effects of Inflation." Journal of Political Economy 70: 521-37.

Kiguel, Miguel A. 1989. "Budget Deficits, Stability, and the Dynamics of Hyperinflation." Journal of Money, Credit and Banking 21: 148-57. 
Kiguel, Miguel A., and Nissan Liviatan. 1990a. "The Inflation-Stabilization Cycles in Argentina and Brazil." Washington: World Bank.

- 1990b. "Some Implications of Policy Games for High Inflation Economies." WPS 379. Washington: Country Economics Department, World Bank.

Kindleberger, Charles P. 1937. International Short-Term Capital Movements. New York: Columbia University Press.

Krugman, Paul. 1979. "A Model of Balance-of-Payments Crises." Journal of Money, Credit and Banking 9: 311-25.

League of Nations. 1926a. The Financial Reconstruction of Austria: General Survey and Principal Documents. Geneva: League of Nations.

League of Nations. 1926b. The Financial Reconstruction of Hungary: General Survey and Principal Documents. Geneva: League of Nations.

- 1946. The Course and Control of Inflation: Review of Monetary Experience in Europe after World War I. Geneva: League of Nations.

Liviatan, Nissan. 1988. "On the Interaction Between Monetary and Fiscal Policies Under Perfect Foresight." Oxford Economic Papers 40: 193-203.

Marquez, Jaime. 1987. "Money Demand in Open Economies: A Currency Substitution Model for Venezuela." Journal of International Money and Finance 6: 167-78.

Melnick, Rafi. 1990. "The Demand for Money in Argentina, 1978-1987: Before and After the Austral Program." Jerusalem: Research Department, Bank of Israel.

Mills, Frederick. 1927. The Behavior of Prices. New York: National Bureau of Economic Research.

Mitchell, Wesley C. 1927. Business Cycles: The Problem and Its Setting. New York: National Bureau of Economic Research.

$\rightarrow$ Montiel, Peter J. 1989. "Empirical Analysis of High-Inflation Episodes in Argentina, Brazil, and Israel." IMF Staff Papers 36: 527-49.

Morales, Juan Antonio. 1988. "Inflation Stabilization in Bolivia." In Inflation Stabilization: The Experience of Israel, Argentina, Brazil, Bolivia, and Mexico, edited by Michael Bruno and others. Cambridge, Mass.: MIT Press.

- 1990. "The Transition from Stabilization to Sustained Growth in Bolivia." Catholic University of Bolivia.

Morales, Juan Antonio, and Jeffrey Sachs. 1989. "Bolivia's Economic Crisis." In Developing Country Debt and the World Economy, edited by Jeffrey D. Sachs. Chicago: University of Chicago Press.

Mussa, Michael. 1981a. "Sticky Individual Prices and the Dynamics of the General Price Level." Carnegie Rochester Conference Series on Public Policy 15: 261-96.

- 1981b. "Sticky Prices and Disequilibrium Adjustment in a Rational Model of the Inflationary Process." American Economic Review 71: 1020 27. 
Nurkse, R. 1944. International Currency Experience: Lessons of the Interwar Period. Geneva: League of Nations (reprinted by Arno Press, 1979).

Obstfeld, Maurice. 1984. "Balance-of-Payments Crises and Devaluation." Journal of Money, Credit and Banking 16: 208-17.

Olivera, Julio H.G. 1967. "Money, Prices and Fiscal Lags: A Note on the Dynamics of Inflation.' Banca Nazionale del Lavoro Quarterly Review 20: 258-67.

Orphanides, Athanasios. 1990. Essays in Macroeconomics. Ph.D. dissertation. Cambridge, Mass.: Massachusetts Institute of Technology.

Ortiz, Guillermo. 1983. "Dollarization in Mexico: Causes and Consequences." In Financial Policies and the World Capital Market: The Problem of Latin American Countries, edited by Pedro Aspe Armella, Rudiger Dornbusch, and Maurice Obstfeld. Chicago: University of Chicago Press.

Pastor, Manuel, Jr. 1990. "Bolivia: Hyperinflation, Stabilization, and Beyond." Los Angeles: Occidental College.

Pazos, Felipe. 1972. Chronic Inflation in Latin America. New York: Praeger Publishers.

Pereira, Luiz Carlos Bresser, and Yoshiaki Nakano. 1987. The Theory of Inertial Inflation: The Foundation of Economic Reform in Brazil and Argentina. Boulder: Lynne Rienner.

Persson, Torsten. 1988. "Credibility of Macroeconomic Policy: An Introduction and a Broad Survey." European Economic Review 32: 519-32.

Piterman, Sylvia. 1988. "The Instability of the Relationship Between Inflation and Real Balances." Bank of Israel, Economic Review 60: 72-83.

Polak, Jacques J. 1943. "European Exchange Depreciation in the Early Twenties." Econometrica 11: 151-62.

$\rightarrow$ Ramirez-Rojas, C. L. 1985. "Currency Substitution in Argentina, Mexico, and Uruguay." IMF Staff Papers 32: 629-67.

Reform Club. 1896. Sound Currency 1895: A Compendium of Accurate and Timely Information on Currency Questions. Intended for Writers, Speakers and Students. New York: Reform Club Sound Currency Committee.

Republic of Poland. 1926. Reports Submitted by the Commission of the American Financial Experts Headed by Dr. E. W. Kemmerer. Warsaw: The Ministry of Finance.

Rist, Charles. 1966. History of Monetary and Credit Theory from John Law to the Present, translated by Jane Degras. New York: A. M. Kelley (reprints of Economic Classics).

Robinson, Joan. 1938. "Reviews: The Economics of Inflation." Economic Journal 48: 507-13.

Rotemberg, Julio J. 1983. "Aggregate Consequences of Fixed Costs of Price Adjustment." American Economic Review 73: 433-36.

$\rightarrow$ Sachs, Jeffrey. 1987. "The Bolivian Hyperinflation and Stabilization." American Economic Review, Papers and Proceedings 77: 279-83.

Sachs, Jeffrey, and Juan Antonio Morales. 1988. "Bolivia: 1952-1986." San Francisco: International Center for Economic Growth. 
Salemi, Michael K., and Thomas J. Sargent. 1979. “The Demand for Money During Hyperinflation Under Rational Expectations: II.' International Economic Review 20: 741-58.

Sargent, Thomas J. 1977. "The Demand for Money During Hyperinflation Under Rational Expectations: I." International Economic Review 18: 59_ 82.

1982. "The Ends of Four Big Inflations." In Inflation: Causes and Effects, edited by Robert E. Hall. Chicago: University of Chicago Press.

Sargent, Thomas J., and Neil Wallace. 1973a. "Rational Expectations and the Dynamics of Hyperinflation." International Economic Review 14: 328-50.

- 1973b. "The Stability of Models of Money and Growth with Perfect Foresight." Econometrica 41: 1043-48.

- 1981. "Some Unpleasant Monetarist Arithmetic." Federal Reserve Bank of Minneapolis Quarterly Review 5: 1-17.

Schelling, Thomas C. 1978. "Thermostats, Lemons, and Other Families of Models.' In Micromotives and Macrobehavior. New York: W. W. Norton and Company.

Seligman, Edwin Robert. 1921. Currency Inflation and Public Debts. New York: The Equitable Trust Company.

Sheshinski, Eytan, and Yoram Weiss. 1983. "Optimum Pricing Under Stochastic Inflation." Review of Economic Studies 59: 513-29.

Shupp, Franklin R. 1976. "Optimal Policy Rules for a Temporary Incomes Policy." Review of Economic Studies 43: 249-59.

Sidrauski, Miguel. 1967. "Inflation and Economic Growth.' Journal of Political Economy 75: 796-810.

Siklos, Pierre L. 1990. "Interpreting a Change in Policy Regimes: A Reappraisal of the First Hungarian Hyperinflation and Stabilization: 1921-1928." Waterloo, Ontario: Wilfrid Laurier University.

Sims, Christopher A., James H. Stock, and Mark W. Watson. 1990. "Inference in Linear Time Series Models with Some Unit Roots."' Econometrica 58: $113-44$.

Sitzler, Fritz. 1924. "The Adaptation of Wages to the Depreciation of the Currency in Germany." International Labour Review 9: 642-66.

Summers, Robert, and Alan Heston. 1988. "A New Set of International Comparisons of Real Product and Price Levels: Estimates for 130 Countries, 1950-1985." The Review of Income and Wealth 34: 1-25.

$\rightarrow$ Tanzi, Vito. 1977. "Inflation, Lags in Collection and the Real Value of Tax Revenue." IMF Staff Papers 24: 154-67.

$\longrightarrow \rightarrow$. 1978. "Inflation, Real Tax Revenue, and the Case for Inflationary Finance: Theory with an Application to Argentina." IMF Staff Papers 25: 417-51.

van Wijnbergen, Sweder. 1988. "Inflation, Balance of Payments Crises, and Public Sector Deficits.' In Economic Effects of the Government Budget, edited by Elhanan Helpman, Assaf Razin, and Efraim Sadka. Cambridge, Mass.: MIT Press. 
Webb, Steven B. 1989. Hyperinflation and Stabilization in Weimar Germany. New York: Oxford University Press.

Wicker, Elmus. 1986. "Terminating Hyperinflation in the Dismembered Habsburg Monarchy." American Economic Review 76: 350-64.

Yeager, Leland B. 1981. Experiences with Stopping Inflation. Washington: American Enterprise Institute.

Young, John P. 1925. European Currency and Finance. Washington: Commission of Gold and Silver Inquiry, U.S. Senate; New York: Garland Publications, 1983. 